University of New Hampshire

University of New Hampshire Scholars' Repository

1-20-1996

\title{
Asian influence over the western North Pacific during the fall season: Inferences from lead 210 , soluble ionic species and ozone
}

Jack E. Dibb

University of New Hampshire, jack.dibb@unh.edu

R. Talbot

University of New Hampshire, robert.talbot@unh.edu

Anthony Klemm

NOAA

G L. Gregory

NASA

H B. Singh

NASA

See next page for additional authors

Follow this and additional works at: https://scholars.unh.edu/earthsci_facpub

Part of the Atmospheric Sciences Commons

\section{Recommended Citation}

Dibb, J. E., R. W. Talbot, K. I. Klemm, G. L. Gregory, H. B. Singh, J. D. Bradshaw, and S. T. Sandholm (1996), Asian influence over the western North Pacific during the fall season: Inferences from lead 210, soluble ionic species and ozone, J. Geophys. Res., 101(D1), 1779-1792, doi:10.1029/94JD03117.

This Article is brought to you for free and open access by the Earth Sciences at University of New Hampshire Scholars' Repository. It has been accepted for inclusion in Earth Sciences Scholarship by an authorized administrator of University of New Hampshire Scholars' Repository. For more information, please contact Scholarly.Communication@unh.edu. 


\section{Authors}

Jack E. Dibb, R. Talbot, Anthony Klemm, G L. Gregory, H B. Singh, J D. Bradshaw, and S T. Sandholm 


\title{
Asian influence over the western North Pacific during the fall season: Inferences from lead 210 , soluble ionic species and ozone
}

\author{
J. E. Dibb, ${ }^{1}$ R. W. Talbot, ${ }^{1}$ K. I. Klemm, ${ }^{1}$ G. L. Gregory, ${ }^{2}$ H. B. Singh, ${ }^{3}$ \\ J. D. Bradshaw, ${ }^{4}$ and S. T. Sandholm ${ }^{4}$
}

\begin{abstract}
Aerosol samples collected over the western Pacific during the NASA/Global Tropospheric Experiment Pacific Exploratory Mission (PEM-West A) expedition (September October 1991) revealed mean ${ }^{210} \mathrm{~Pb}$ concentrations in the free troposphere in the $5-10 \mathrm{fCi} \mathrm{m}^{-3}$ STP range. Most soluble ionic aerosol-associated species were near detection limits $[<40$ parts per trillion by volume (pptv)] in these same samples. The altitude distribution of $\mathrm{O}_{3}$ near Asia closely resembled that of ${ }^{210} \mathrm{~Pb}$, while no relationship was found between the concentrations of $\mathrm{O}_{3}$ and ${ }^{7} \mathrm{Be}$. Free tropospheric air over the western Pacific was depleted in soluble aerosol-associated species but enriched in ${ }^{210} \mathrm{~Pb}$ and $\mathrm{O}_{3}$, indicative of deep wet convection over the Asian continent. The influence of Asian air on the composition of the free troposphere over the western Pacific was evident on most of the PEM-West A flights. However, evidence of continental influence was largely restricted to those species that are relatively insoluble (or have insoluble precursors), hence escape scavenging during vertical transport from the boundary layer into the free troposphere by wet convective activity.
\end{abstract}

\section{Introduction}

It is well established that Asian air transported eastward in the free troposphere causes peak concentrations of mineral aerosols at a number of remote Pacific island sites, especially in the spring [e.g., Prospero et al., 1985; Merrill et al., 1989; Gao et al., 1992]. This transport pattern, combined with increasing industrialization in the Asian region, suggests that anthropogenic emissions in Asia may play an increasing role in the composition of the atmosphere over the western North Pacific. The objective of the Pacific Exploratory Mission (PEM-West A) airborne sampling campaign in September - October 1991 was to characterize the composition of the Pacific atmosphere near Asia during the fall season, when the outflow of Asian dust was expected to be near the low point in its seasonal cycle. The NASA Ames DC8, with an extensive load of remote and in situ atmospheric chemistry instrumentation, flew 17 missions, totaling 120 hours, over the Pacific Ocean toward this end (see overview by Hoell et al. [this issue]). The follow-up mission, PEM-West B, was flown in the same regions in February - March 1994 to characterize the spring period when the continental influence was expected to be stronger. Analyses of results from PEM-West B are in progress and will be reported in later papers.

This paper discusses the composition of aerosol samples collected during PEM-West $\mathrm{A}$. Concentrations of a suite of watersoluble ionic species $\left(\mathrm{Cl}^{-}, \mathrm{NO}_{3}^{-}, \mathrm{SO}_{4}{ }^{-}, \mathrm{MSA}, \mathrm{C}_{2} \mathrm{O}_{4}^{-}, \mathrm{PO}_{4}{ }^{3-}, \mathrm{Na}^{+}\right.$,

\footnotetext{
${ }^{1}$ Institute for the Study of Earth, Oceans and Space, University of New Hampshire, Durham.

${ }^{2}$ Atmospheric Sciences Division, NASA Langley Research Center, Hampton, Virgina.

${ }^{3}$ NASA Ames Research Center, Moffet Field, California.

${ }^{4}$ Georgia Institute of Technology, Atlanta.
}

Copyright 1996 by the American Geophysical Union.

Paper number 94JD03117.

0148-0227/96/94JD-03117\$05.00
$\mathrm{NH}_{4}^{+}, \mathrm{K}^{+}, \mathrm{Mg}^{2+}$, and $\mathrm{Ca}^{2+}$ ) and the natural radionuclides ${ }^{210} \mathrm{~Pb}$ and ${ }^{7} \mathrm{Be}$ were determined. Lead 210 and ${ }^{7} \mathrm{Be}$ have well-defined sources and simple atmospheric chemistry, making them valuable tracers of continental and upper troposphere/lower stratosphere air, respectively [see Dibb et al., 1992, and references therein]. We focus on the spatial and altitudinal distribution of ${ }^{210} \mathrm{~Pb}$ and its relationship to the distributions of other aerosol-associated and gaseous species measured during PEM-West A, in order to assess the influence of Asian air on the composition of the Pacific atmosphere. Several companion papers address this same question with additional tracers and meteorological analyses [Browell et al., this issue; Gregory et al., this issue; Smyth et al., this issue; Talbot et al., this issue]; these independent approaches validate the utility of ${ }^{210} \mathrm{~Pb}$ as a tracer of continentally influenced air over the Pacific.

\section{Methods}

\section{Sampling}

Aerosol samples for radionuclide and soluble ionic analyses were collected on separate $90-\mathrm{mm}$-diameter, $2-\mu \mathrm{m}$ pore size, Zefluor filters. Two sampling systems (see below) were operated in parallel, so that exposure times for the radionuclide and ionic samples were identical. Sampling was restricted to flight legs at constant altitude. During the intensive flights this resulted in filter exposure periods generally between 20 and $45 \mathrm{~min}$ in duration. On transit flights with long constant altitude legs, aerosol filters were changed at 45- to 60 -min intervals. The volume of sampled air thus ranged $1.4-17.5 \mathrm{~m}^{3} \mathrm{STP}$. Two to eight samples were collected on each of the 17 flights during PEM-West $A$.

Collecting aerosol samples without altering the characteristics of the ambient aerosol population is never a trivial problem; high-speed airborne platforms present additional challenges in this regard [e.g., Huebert et al., 1990; Porter et al, 1992]. As a participant in NASA's Global Tropospheric Experiment (GTE) since 1983, RWT has continuously refined sampling systems to reduce differences between the ambient and sampled aerosol 
populations (R.W. Talbot et al., Improvements in aerosol inlet performance in airborne applications, submitted to Journal of Geophysical Research, 1995 hereinafter referred to as T95). Two identical aerosol sampling probes were employed during PEMWest $A$. These consisted of curved leading edge nozzles $(0.7-\mathrm{cm}$ diameter) positioned on the centerline of a $15.2-\mathrm{cm}$ diameter by 40.6-cm-long shroud. The leading edge of the inlet nozzle was $19.0 \mathrm{~cm}$ back from the leading edge of the shroud. Nozzles with a curved leading edge design have been shown to reduce aerosol losses due to turbulence within the inlet when compared to nozzles with sharp leading edges [Porter et al., 1992; T95]. Locating the nozzle within a shroud results in air streamlines that are mbre nearly parallel to the nozzle's long axis, again helping to redulue aerosol losses from flow-separation induced turbulence inside the inlet just downstream of the nozzle's leading edge [McFarland et al., 1989; Cain et al., 1993; T95]. The nozzle ID increased from 0.7 to $5.0 \mathrm{~cm}$ over a length of $23.0 \mathrm{~cm}$ and then attached to $5.0-\mathrm{cm}$ ID seamless stainless steel inlet tubing. This tubing bent $45^{\circ}$ with a $46-\mathrm{cm}$ radius of curvature to penetrate the fuselage.

Both aerosol probes were mounted on the same $62^{\circ}$ port on the upper left side of the DC-8, $1194 \mathrm{~cm}$ from the nose of the plane. Air telocity within the shrouds was monitored with pitot tubes withlin the shroud and the static air temperature measured by GTE project instrumentation and was found to be essentially equal to the true air speed. Sampling flow rates were adjusted to ensure that air velocities through the nozzles were within $5-10 \%$ of true air speed at all altitudes. Integrating linear mass flow meters (Teledyne-Hastings Radist) were used to measure flow rates and the volume of air sampled.

\section{Analysis}

The filters for soluble ionic analyses were extracted in the field within 12 hours of each flight, following procedures that have been previously described [Talbot et al., 1986, 1992]. These extracts were analyzed for anionic species by ion chromatography immediately after extraction. Aliquots preserved with chloroform were subsequently analyzed for cationic species, again by ion chromatography, in the laboratory at the University of New Hampshire (UNH) after completion of the mission.

All filters for radionuclide analyses were subjected to nondestructive gamma spectrometry at UNH within 2 - 4 weeks of collection to quantify ${ }^{7} \mathrm{Be}$ activities [Dibb, 1990a; Dibb et al., 1992]. (Groups of filters were express mailed to New Hampshire from the field sites at weekly intervals.) Uncertainties in ${ }^{7} \mathrm{Be}$ activity due to counting statistics were below $20 \%$ for 16 -hour counting periods when the activity exceeded $100 \mathrm{fCi} \mathrm{m}^{-3}$ but increased for samples with lower activity. The small air volumes sampled precluded quantification of ${ }^{210} \mathrm{~Pb}$ by direct gamma counting. We determined ${ }^{210} \mathrm{~Pb}$ activities by alpha spectrometric determination of ${ }^{210} \mathrm{Po}$ (with ${ }^{208} \mathrm{Po}$ tracer added and plating onto $\mathrm{Ag}$ planchets) [Flynn, 1968; Dibb, 1990b] after allowing 1 year for ${ }^{210} \mathrm{Po}$ ingrowth. The ${ }^{210} \mathrm{Po} /{ }^{210} \mathrm{~Pb}$ ratio will be $85-90 \%$ of its value at secular equilibrium after $12-14$ months (the last samples were processed 2 months after the first), assuming that the aerosols were so young at collection that no ${ }^{210}$ Po was present. We did not correct the ${ }^{210} \mathrm{~Pb}$ activities reported below for this departure from equilibrium, hence they may be as much as $10-15 \%$ low. The sensitivity of this technique is quite good and can be improved simply by accumulating counts for a longer time period, provided the background count rate is low and stable. (In theory, the same is true for gamma spectrometry, but the short half-life of ${ }^{7} \mathrm{Be}$ precludes very long counting periods, particularly when there is a sample backlog.) For this study, four samples were counted concurrently until the uncertainty due to counting statistics of the least active sample in each group dropped below $15 \%$, or 8 days had passed. Most samples were counted 3 - 6 days, with $1 / 4$ having uncertainties of $14-15 \%$ and the rest lower.

Detection limits for the aerosol-associated species were defined as 2 times the standard deviation of the concentration of each analyte determined in $\mathbf{4 0}$ blank filters, generated at a rate of at least 2 for each flight, divided by the volume of air collected for a particular sample. For the mean volume of air sampled during PEM-West A ( $8.9 \mathrm{~m}^{-3} \mathrm{STP}$ per sample), detection limits would be $0.5 \mathrm{fCi}^{210} \mathrm{~Pb} \mathrm{~m}^{-3} \mathrm{STP}, 10 \mathrm{fCi}^{7} \mathrm{Be} \mathrm{m}^{-3} \mathrm{STP}, 30 \mathrm{pptv} \mathrm{Cl}^{-}, 5$ parts per trillion by volume (pptv) $\mathrm{NO}_{3}^{-}, 9$ pptv $\mathrm{SO}_{4}=, 1 \mathrm{pptv} \mathrm{MSA}$, 2 pptv $\mathrm{C}_{2} \mathrm{O}_{4}=, 20$ pptv $\mathrm{PO}_{4}{ }^{3-}, 40$ pptv $\mathrm{Na}^{+}, 25$ pptv $\mathrm{NH}_{4}+$, 17 pptv $\mathrm{K}^{+}, 6 \mathrm{pptv} \mathrm{Mg}^{2+}$, and 14 pptv $\mathrm{Ca}^{2+}$. Analytical details for other species discussed in this paper are provided in companion papers in this issue. All of the data are archived at and available from the NASA/GTE project office.

\section{Results}

A total of 98 aerosol samples were collected during PEM-West A. All of the samples had ${ }^{210} \mathrm{~Pb}$ activities that could be quantified by our techniques, while ${ }^{7} \mathrm{Be}$ and $\mathrm{SO}_{4}{ }^{-}$were quantified in 82 and 90 samples, respectively. Nitrate and $\mathrm{NH}_{4}^{+}$mixing ratios were also high enough to quantify in more than $1 / 2$ the samples, but all other soluble ionic species were below our detection limits more often than not (Table 1). Mean concentrations of all aerosolassociated species, except ${ }^{7} \mathrm{Be}$, were higher in the 0 - to $2-\mathrm{km}$ altitude range than at higher elevations. This difference would be accentuated for most of the ionic species if all samples below detection limit were included in the averaging process (Table 1).

We expected ${ }^{210} \mathrm{~Pb}$ activities to decrease rapidly with altitude and ${ }^{7} \mathrm{Be}$ activities to increase. However, the observed contrasts between boundary layer and free tropospheric activities of ${ }^{7} \mathrm{Be}$ and ${ }^{210} \mathrm{~Pb}$ were quite small. Nearly $1 / 2$ of the samples above $2 \mathrm{~km}$ were collected between 6 and $13 \mathrm{~km}$ where ${ }^{210} \mathrm{~Pb}$ activities near or below $2 \mathrm{fCi} \mathrm{m}^{-3}$ STP were expected [e.g., Moore et al., 1973; Lambert et al., 1982], yet the PEM-West A mean was $4 \mathrm{fCi} \mathrm{m}^{-3}$ STP (Table 1). Middle and upper troposphere mean ${ }^{7} \mathrm{Be}$ activities in the $400-1000 \mathrm{fCi} \mathrm{m}^{-3}$ range have been previously reported for several regions [Bhandari et al., 1966; Dutkiewicz and Husain, 1979, 1985; Dibb et al., 1992]; the mean measured over the western Pacific is more than twofold lower than these values (Table 1). This aggregated overview suggests "too much" ${ }^{210} \mathrm{~Pb}$ and "too little" ${ }^{7} \mathrm{Be}$ were present in the free troposphere over the western Pacific.

Many of the PEM-West A flights were characterized by vertical separation of marine and continental air masses. Similar layering has also been reported for the eastern Pacific [Paluch et al., 1992]. Talbot et al. [this issue] and Gregory et al. [this issue] use a combination of meteorological analyses and chemical tracers to identify periods when the DC-8 was clearly sampling air that had been over land within 5 days before it was encountered (continental) or had not passed over land in the previous 10 days (marine), respectively. We adopt the same air mass classifications to stratify the aerosol composition data (Table 2). Nitrate, $\mathrm{SO}_{4}=$, and $\mathrm{NH}_{4}^{+}$were the only soluble ionic species detected above the boundary layer in this subset of the data. These three species plus $\mathrm{Na}^{+}$and $\mathrm{Mg}^{2+}$ were slightly enhanced in northern versus southern hemisphere marine boundary layer air. Free-tropospheric marine air in the northern hemisphere showed $\mathrm{NH}_{4}{ }^{+}$enhancement relative to that from the southern hemisphere. Not surprisingly, continen- 
Table 1. Summary of the Radionuclide Activities and Soluble Ionic Concentrations in all Aerosol Samples Collected During PEM-West A

\begin{tabular}{|c|c|c|c|c|c|c|c|c|c|c|c|c|}
\hline${ }^{210} \mathrm{~Pb}$ & ${ }^{7} \mathrm{Be}$ & $\mathrm{Cl}^{-}$ & $\mathrm{NO}_{3}^{-}$ & $\mathrm{SO}_{4}=$ & MSA & $\mathrm{C}_{2} \mathrm{O}_{4}^{*}$ & $\mathrm{PO}_{4}{ }^{3 \cdot}$ & $\mathrm{Na}^{+}$ & $\mathrm{NH}_{4}^{+}$ & $\mathrm{K}^{+}$ & $\mathrm{Mg}^{2+}$ & $\mathrm{Ca}^{2+}$ \\
\hline \multicolumn{13}{|c|}{$0-2 \mathrm{~km}$} \\
\hline $\begin{array}{l}5.6 \\
(5.9) \\
25\end{array}$ & $\begin{array}{l}112 \\
(83) \\
17\end{array}$ & $\begin{array}{l}313 \\
(73) \\
23\end{array}$ & $\begin{array}{l}52 \\
(66) \\
23\end{array}$ & $\begin{array}{l}266 \\
(368) \\
24\end{array}$ & $\begin{array}{l}3.2 \\
(2.0) \\
8\end{array}$ & $\begin{array}{l}6.1 \\
(5.4) \\
17\end{array}$ & $\begin{array}{l}92 \\
(41) \\
3\end{array}$ & $\begin{array}{l}390 \\
(584) \\
22\end{array}$ & $\begin{array}{l}402 \\
(565) \\
21\end{array}$ & $\begin{array}{l}40 \\
(63) \\
14\end{array}$ & $\begin{array}{l}54 \\
(67) \\
21\end{array}$ & $\begin{array}{l}72 \\
(92) \\
8\end{array}$ \\
\hline \multicolumn{13}{|c|}{$2-13 \mathrm{~km}$} \\
\hline $\begin{array}{l}4.1^{\mathrm{B}} \\
(3.4) \\
65\end{array}$ & $\begin{array}{l}218^{\circ} \\
(160) \\
59\end{array}$ & $\begin{array}{l}132 \\
(104) \\
4\end{array}$ & $\begin{array}{l}25 \\
(24) \\
34\end{array}$ & $\begin{array}{l}51 \\
(71) \\
66\end{array}$ & 11 & $\begin{array}{l}4.1 \\
(60) \\
17\end{array}$ & $\begin{array}{l}83 \\
(46) \\
6\end{array}$ & $\begin{array}{l}144 \\
(108) \\
18\end{array}$ & $\begin{array}{l}67 \\
(113) \\
32\end{array}$ & $\begin{array}{l}10 \\
(11) \\
30\end{array}$ & $\begin{array}{l}17 \\
(11) \\
13\end{array}$ & $\begin{array}{l}38 \\
(35) \\
14\end{array}$ \\
\hline \multicolumn{13}{|c|}{ Detection Limits } \\
\hline 0.2 & 10 & 30 & 5 & 9 & 1 & 2 & 20 & 40 & 25 & 17 & 6 & 14 \\
\hline
\end{tabular}

Activities of ${ }^{210} \mathrm{~Pb}$ and ${ }^{7} \mathrm{Be}$ are reported in $\mathrm{fCi} \mathrm{m}^{-3} \mathrm{STP}$, all ionic concentrations in parts per trillion by volume. Simple arithmetic means (with standard deviation) are given for all samples above detection limits. The number of such samples is shown in italics; ${ }^{210} \mathrm{~Pb}$ was detected in all samples, but all other species were below detection limits in at least one sample.

"A total of 73 filters were collected at altitudes above $2 \mathrm{~km}$. Eight of these were on the transit flights at altitudes between 9.8 and $11 \mathrm{~km}$, in the lower stratosphere or upper tropospheric air with large stratospheric influence. These filters were not analyzed for ${ }^{210} \mathrm{~Pb}$, nor were the ${ }^{7} \mathrm{Be}$ concentrations included in the averages above. Including the mean ${ }^{7} \mathrm{Be}$ concentration on these eight filters $\left(2134 \mathrm{fCi} \mathrm{m}^{-3} \mathrm{STP}\right)$ raises the overall mean above $2 \mathrm{~km}$ to $428 \mathrm{fCi} \mathrm{m}^{-3} \mathrm{STP}$.

tally derived air showed large enhancements of all soluble ionic species except $\mathrm{Cl}^{-}$and MSA. However, this impact was largely restricted to the boundary layer. Sulfate, $\mathrm{NH}_{4}{ }^{+}$, and perhaps $\mathrm{NO}_{3}^{-}$ concentrations were also elevated in continental outflow between 1 and $7 \mathrm{~km}$ (Table 2).

Activities of ${ }^{2 ! 0} \mathrm{~Pb}$ and ${ }^{7} \mathrm{Be}$ were lowest in southern hemisphere marine air at all elevations (Table 2), suggesting a lengthy aging period since any continental influence and efficient removal of submicron aerosols. Comparing ${ }^{210} \mathrm{~Pb}$ concentrations in aged marine air between hemispheres suggests a diffuse continental influence at all altitudes in the north. Concentrations of ${ }^{210} \mathrm{~Pb}$ were higher in continental outflow than northern aged marine air, but this was hardly unexpected since ${ }^{210} \mathrm{~Pb}$ was one of the tracers used to define continental influence [Talbot et al., this issue]. In the northern hemisphere, ${ }^{210} \mathrm{~Pb}$ activities in the $1-$ to $7-\mathrm{km}$ altitude range were higher than the mean below $1 \mathrm{~km}$ in both aged marine and clearly continentally influenced air, in contrast to the anticipated rapid decrease with height. Similarly, ${ }^{7} \mathrm{Be}$ distributions

Table 2. Composition of Aerosols in Air Masses Characterized As Marine Versus Continental [see Talbot et al., this issue] for Discussion of Criteria Used to Define Air Mass Types

\begin{tabular}{|c|c|c|c|c|c|c|c|c|c|c|c|c|}
\hline$n^{4}$ & Alt km & ${ }^{210} \mathrm{~Pb}$ & ${ }^{7} \mathbf{B e}$ & $\mathrm{Cl}^{-}$ & $\mathrm{NO}_{3}^{-}$ & nss-SO ${ }_{4}{ }^{2}$ & MSA & $\mathrm{NH}_{4}{ }^{+}$ & $\mathrm{Na}^{+}$ & $\mathrm{K}^{+}$ & $\mathrm{Mg}^{2+}$ & $\mathrm{Ca}^{2+}$ \\
\hline \multicolumn{13}{|c|}{ Southern Hemisphere Aged Marine } \\
\hline 2 & $<1$ & $\begin{array}{l}0.4 \\
(0.4)\end{array}$ & $\begin{array}{l}27 \\
(23)\end{array}$ & $\begin{array}{l}224 \\
(59)\end{array}$ & $<5$ & $\begin{array}{l}20 \\
(12)\end{array}$ & $<1$ & $\begin{array}{l}33 \\
(11)\end{array}$ & $\begin{array}{l}66 \\
(9)\end{array}$ & $<17$ & $\begin{array}{l}15 \\
(2.1)\end{array}$ & $<14$ \\
\hline 2 & $1-7$ & $\begin{array}{l}0.7 \\
(0.3)\end{array}$ & $\begin{array}{l}43 \\
(46)\end{array}$ & $<30$ & $\begin{array}{l}17 \\
(9)\end{array}$ & $\begin{array}{l}18 \\
(13)\end{array}$ & $<1$ & $<25$ & $<40$ & $<17$ & $<6$ & $<14$ \\
\hline 4 & $7-13$ & $\begin{array}{l}0.6 \\
(0.2)\end{array}$ & $\begin{array}{l}95 \\
(98)\end{array}$ & $<30$ & $\begin{array}{l}21 \\
(28)\end{array}$ & $\begin{array}{l}22 \\
(9)\end{array}$ & $<1$ & $<25$ & $<40$ & $<17$ & $<6$ & $<14$ \\
\hline \multicolumn{13}{|c|}{ Northern Hemisphere Aged Marine } \\
\hline 9 & $<1$ & $\begin{array}{l}4.0 \\
(1.7)\end{array}$ & $\begin{array}{l}43 \\
(71)\end{array}$ & $\begin{array}{l}157 \\
(69)\end{array}$ & $\begin{array}{l}17 \\
(9)\end{array}$ & $\begin{array}{l}142 \\
(98)\end{array}$ & $\begin{array}{l}1.4 \\
(0.7)\end{array}$ & $\begin{array}{l}103 \\
(43)\end{array}$ & $\begin{array}{l}246 \\
(249)\end{array}$ & $<17$ & $\begin{array}{l}35 \\
(31)\end{array}$ & $<14$ \\
\hline 8 & $1-7$ & $\begin{array}{l}5.4 \\
(2.7)\end{array}$ & $\begin{array}{l}218 \\
(97)\end{array}$ & $<30$ & $\begin{array}{l}10 \\
(12)\end{array}$ & $\begin{array}{l}45 \\
(31)\end{array}$ & $<1$ & $\begin{array}{l}30 \\
(15)\end{array}$ & $<40$ & $<17$ & $<6$ & $<14$ \\
\hline 25 & $7-13$ & $\begin{array}{l}2.4 \\
(1.6)\end{array}$ & $\begin{array}{l}151 \\
(135)\end{array}$ & $<30$ & $\begin{array}{l}15 \\
(18)\end{array}$ & $\begin{array}{l}21 \\
(17)\end{array}$ & $<1$ & $\begin{array}{l}35 \\
(15)\end{array}$ & $<40$ & $<17$ & $<6$ & $<14$ \\
\hline \multicolumn{13}{|c|}{ Asian Continental Outflow } \\
\hline $2^{\mathrm{b}}$ & $<1$ & $\begin{array}{l}23.0 \\
(0.7)\end{array}$ & $\begin{array}{l}121 \\
(89)\end{array}$ & $\begin{array}{l}263 \\
(174)\end{array}$ & $\begin{array}{l}239 \\
(51)\end{array}$ & $\begin{array}{l}1363 \\
(219)\end{array}$ & $<1$ & $\begin{array}{l}1938 \\
(446)\end{array}$ & $\begin{array}{l}1053 \\
(957)\end{array}$ & $\begin{array}{l}156 \\
(121)\end{array}$ & $\begin{array}{l}101 \\
(64)\end{array}$ & $\begin{array}{l}51 \\
(19)\end{array}$ \\
\hline 8 & $<1$ & $\begin{array}{l}5.5 \\
(3.3)\end{array}$ & $\begin{array}{l}101 \\
(95)\end{array}$ & $\begin{array}{l}140 \\
(108)\end{array}$ & $\begin{array}{l}61 \\
(37)\end{array}$ & $\begin{array}{l}325 \\
(159)\end{array}$ & $\begin{array}{l}2.3 \\
(1.2)\end{array}$ & $\begin{array}{l}489 \\
(192)\end{array}$ & $\begin{array}{l}149 \\
(81)\end{array}$ & $\begin{array}{l}26 \\
(28)\end{array}$ & $\begin{array}{l}65 \\
(93)\end{array}$ & $<14$ \\
\hline 7 & $1-7$ & $\begin{array}{l}11.5 \\
(3.1)\end{array}$ & $\begin{array}{l}235 \\
(103)\end{array}$ & $<30$ & $\begin{array}{l}38 \\
(46)\end{array}$ & $\begin{array}{l}104 \\
(101)\end{array}$ & $<1$ & $\begin{array}{l}273 \\
(387)\end{array}$ & $<40$ & $<17$ & $<6$ & $<14$ \\
\hline 7 & $7-13$ & $\begin{array}{l}7.7 \\
(3.4)\end{array}$ & $\begin{array}{l}222 \\
(226)\end{array}$ & $<30$ & $\begin{array}{l}13 \\
(15)\end{array}$ & $\begin{array}{l}32 \\
(15)\end{array}$ & $<1$ & $\begin{array}{l}30 \\
(10)\end{array}$ & $<40$ & $<17$ & $<6$ & $<14$ \\
\hline
\end{tabular}

The mean activities (and standard deviations) for the radionuclides are given in $\mathrm{fCi}^{-3} \mathrm{STP}$, soluble ionic concentrations (and standard deviations in parts per trillion by volume. For the cases when an ionic species was not quantifiable, the concentration is reported as less than the mean detection limit.

an Number of samples used to derive these average values.

'Very strong outflow at low altitude on flight 13 was separated from other low-altitude samples impacted by continental outflow. 
A Flights $6-13$
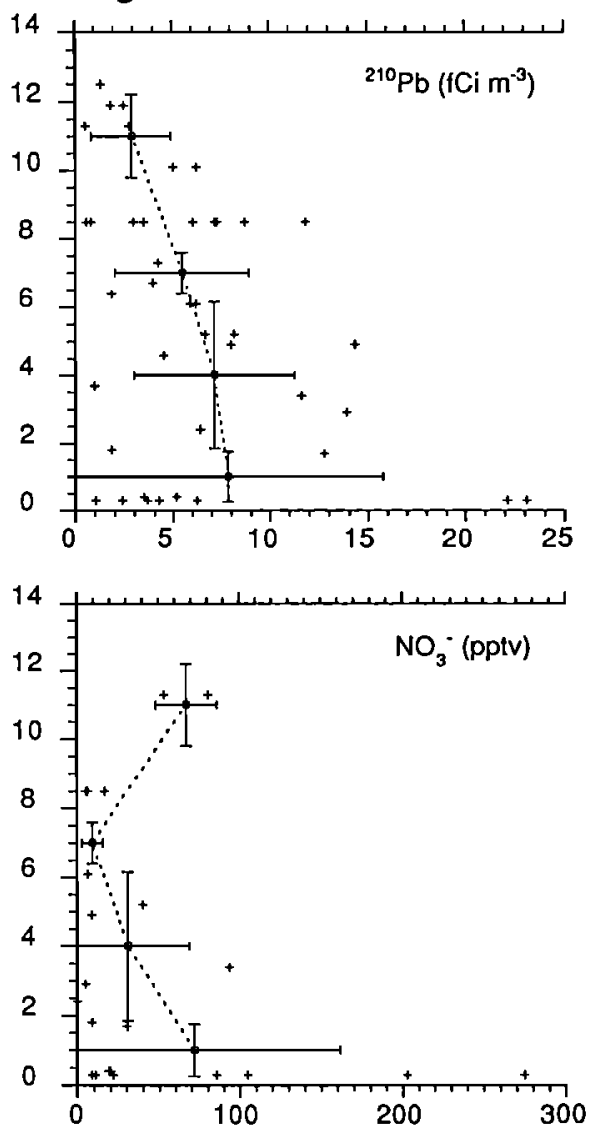
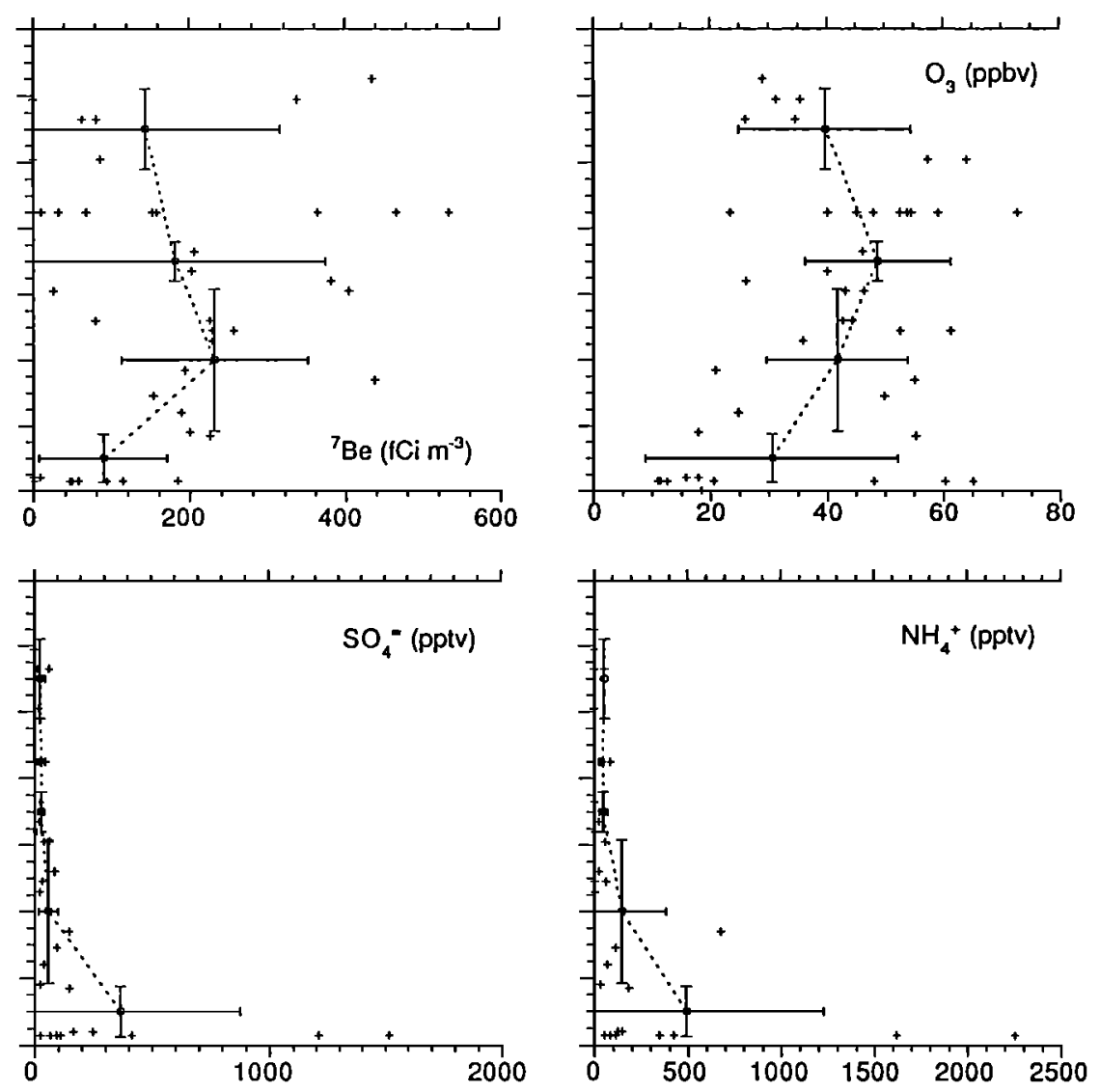

Figure 1. Altitude distributions of the concentrations of all aerosol species that were detected in more than $1 / 2$ the samples. Average $\mathrm{O}_{3}$ concentrations during the period when each aerosol sample was collected are also shown. Average concentrations were calculated for four altitude bins, these are shown as pluses, with the horizontal arms representing standard deviations and vertical arms the altitude range. Results have been separated on the basis of location into a near-Asia group (a) and those over more remote regions of the western Pacific (b).

departed from expectations, showing little or no increase with height in the free troposphere in the northern hemisphere, and only a twofold to threefold increase between the boundary layer and free troposphere in both continental and aged marine air masses (Table 2).

\section{Discussion}

Binning the aerosol data by altitude band and air mass type (Table 2) suggests that the free troposphere in the PEM-West A study area was depleted in all aerosol-associated species except ${ }^{210} \mathrm{~Pb}$. Such binning also highlights the scarcity of soluble ionic species data. The very low ambient concentrations of most of these species limits quantitative interpretation or discussion of the composition of the soluble fraction of the aerosol. We will thus emphasize the results for the radionuclides, particularly ${ }^{210} \mathrm{~Pb}$, and their relation to other observations made from the DC-8. We will also abandon the air mass classifications discussed above in favor of dividing the data into two geographic regions; near Asia and over the remote Pacific. All samples collected during flights 6 -13 when the plane was based in Yokota and Hong Kong are considered near Asia. Flights 14 - 19 sampled a broad region over the remote western Pacific, mainly around Guam but including the transit flights to Wake Island and Honolulu [see Hoell et al., this issue]. It should be noted that this division introduces a southward shift in latitude in addition to the eastward shift farther from the
Asian continent, as flights 14 - 19 were mainly conducted in tropical and subtropical regions.

\section{Continental Influence, Lead-210 and Ozone Relationships}

Altitude distributions of ${ }^{210} \mathrm{~Pb}$ over the western Pacific are shown in Figure 1, with the distributions of all other aerosol-associated species that were detected in at least $1 / 2$ the samples. Average in situ $\mathrm{O}_{3}$ concentrations during each aerosol collection interval are also shown. The low concentrations of ${ }^{7} \mathrm{Be}$ and soluble ionic species in the free troposphere are clearly evident in this figure, both near Asia and farther east. Ozone mixing ratios in the free troposphere near Asia ranged 1.5- to threefold higher than in the corresponding altitude ranges over the remote Pacific, with the largest enhancements observed between 2 and $8.5 \mathrm{~km}$ (Figure 1). Mean concentrations of ${ }^{210} \mathrm{~Pb}$ near Asia in the 2- to $8.5-\mathrm{km}$ altitude range were comparable to those in the boundary layer; if the two boundary layer samples with ${ }^{210} \mathrm{~Pb}$ concentrations $>23 \mathrm{fCi} \mathrm{m}$ ${ }^{3}$ STP are ignored, the concentrations in the 2- to 7 and 7- to $8.5-\mathrm{km}$ bins generally exceeded those in the boundary layer (Figure 1a).

Much of the scatter within altitude bins in Figure 1 is the result of combining data from all flights in each of the respective regions. Profiles for individual flights are data sparse but indicate that air masses with elevated concentrations of ${ }^{210} \mathrm{~Pb}$ and $\mathrm{O}_{3}$ were generally restricted to narrow altitude ranges on any given flight. 
Flights $14 \cdot 19$
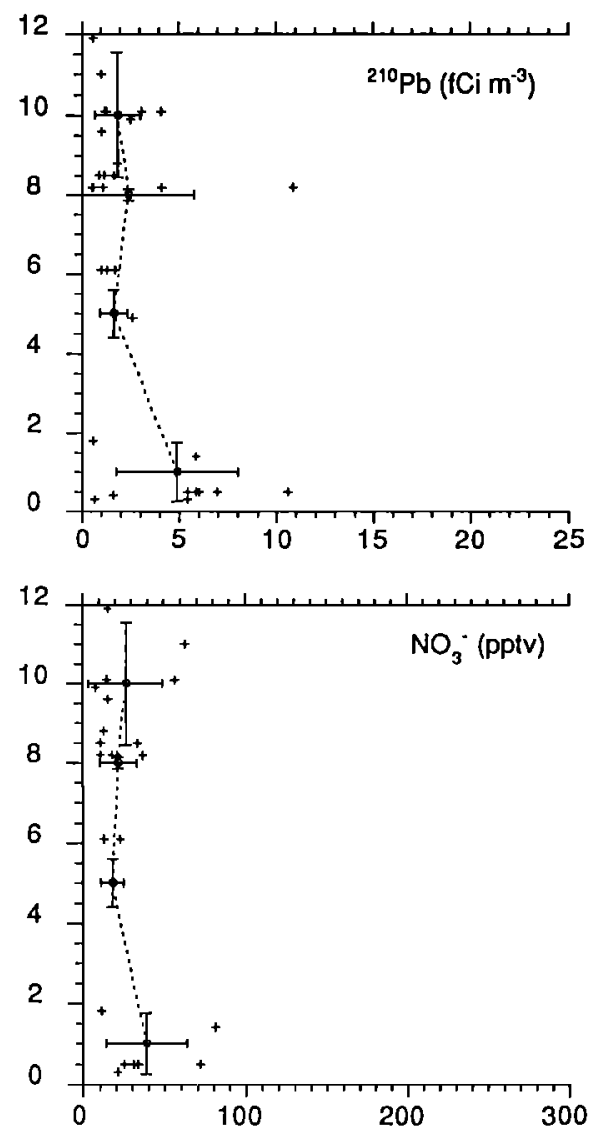
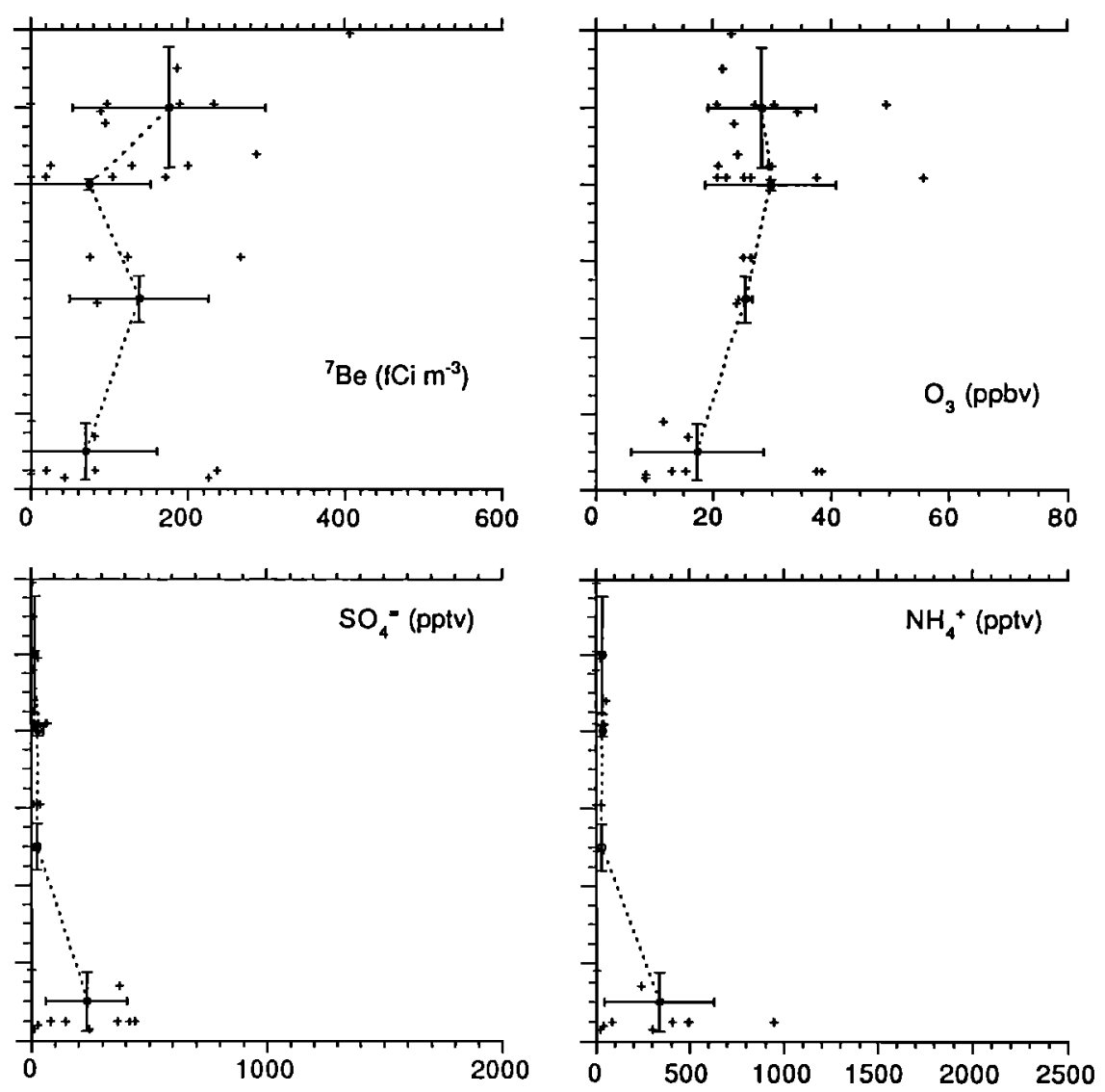

Figure 1. (continued)

Occurrence of such layers at different heights on different days causes the general enhancement of ${ }^{210} \mathrm{~Pb}$ and $\mathrm{O}_{3}$ between 2 and $8.5 \mathrm{~km}$ near Asia (Figure 1a).

The samples collected on flight 12 provide a clear example of the vertical layering encountered offshore of the Asian continent (Figure 2). Ozone and ${ }^{210} \mathrm{~Pb}$ concentrations increased substantially in the two samples collected above $8 \mathrm{~km}$. In contrast, ${ }^{7} \mathrm{Be}$ concentrations dropped in this altitude range, to levels $>$ twofold lower than those measured between 1.5 and $6.5 \mathrm{~km}$. Nitrate and $\mathrm{NH}_{4}^{+}$concentrations were only above detection limits in the bottom $2 \mathrm{~km}$ of the profile, while $\mathrm{SO}_{4}{ }^{=}$concentrations decreased more than tenfold between the boundary layer and all higher elevations. Meteorological and trajectory analyses indicate that the air masses sampled at the top of this profile had been recently advected from the Asian continent, while the air masses intercepted at lower levels had originated farther east over the Pacific [Bachmeier et al., this issue; Merrill, this issue].

Scatterplots of $\mathrm{O}_{3}$ versus ${ }^{210} \mathrm{~Pb}$ for each altitude/location bin provide a closer look at the apparent similarity of the variation with altitude of these two species (Figure 3). Near Asia there was a tendency for covariation of ${ }^{210} \mathrm{~Pb}$ and $\mathrm{O}_{3}$ at all altitudes. Below $8.5 \mathrm{~km} \mathrm{a} 1 \mathrm{fCi} \mathrm{m} \mathrm{m}^{-3} \mathrm{STP}$ increase of ${ }^{210} \mathrm{~Pb}$ was associated with an unexpectedly consistent 2.4 parts per billion by volume (ppbv) increase in the $\mathrm{O}_{3}$ mixing ratio. Similar trends were found over the remote Pacific in the boundary layer and in the 7- to $8.5-\mathrm{km}$ range (Figure 3). Ozone mixing ratios decrease less than ${ }^{210} \mathrm{~Pb}$ activities between 7 and $8.5 \mathrm{~km}$ and higher altitudes in both regions, but the two species continue to covary (Figures 1 and 3).
The statistical significance of the relationships between ${ }^{210} \mathrm{~Pb}$ and $\mathrm{O}_{3}$ (Figure 3 ) is limited by the small number of observations, but consideration of atmospheric dynamics over Asia and the western Pacific suggests they are real. Specifically, deep convection over the Asian continent has been shown to rapidly transport ${ }^{222} \mathrm{Rn}$ to the middle and upper troposphere, where it can then be advected eastward over much of the northern Pacific [Kritz et al., 1990; Balkanski et al., 1992]. Recent measurements in the lower stratosphere north of Australia have shown that large tropical cyclones with heavy precipitation can rapidly transport boundary layer ${ }^{222} \mathrm{Rn}$ up to, and through, the tropopause [Kritz et al., 1993; Danielsen, 1993]. Efficient scavenging of aerosols and soluble gases in deep wet convection would provide a source of middle to upper tropospheric air with low concentrations of aerosolassociated species [Kleinman and Daum, 1991]. Decay of the ${ }^{222} \mathrm{Rn}$ lifted by such convection would constitute a source of ${ }^{210} \mathrm{~Pb}$ at higher elevations where precipitation scavenging is greatly reduced. Sparingly soluble $\mathrm{O}_{3}$ and $\mathrm{O}_{3}$ precursors as well as other gases like $\mathrm{CO}$ would also survive processing through wet convective updrafts [e.g., Newell et al., 1988; Kleinman and Daum, 1991; Pickering et al., 1992].

We hypothesize that frequent wet convection over Asia during the autumn season characterized in PEM-West $\mathrm{A}$ was the mechanism responsible for the free tropospheric aerosol distributions and ${ }^{210} \mathrm{~Pb}-\mathrm{O}_{3}$ relationships described above. On the other hand, stratospheric air is also enriched in $\mathrm{O}_{3}$ and depleted in aerosols, suggesting that injection of stratospheric air into the middle troposphere could account for the altitude distributions we observed. 
Flight 12
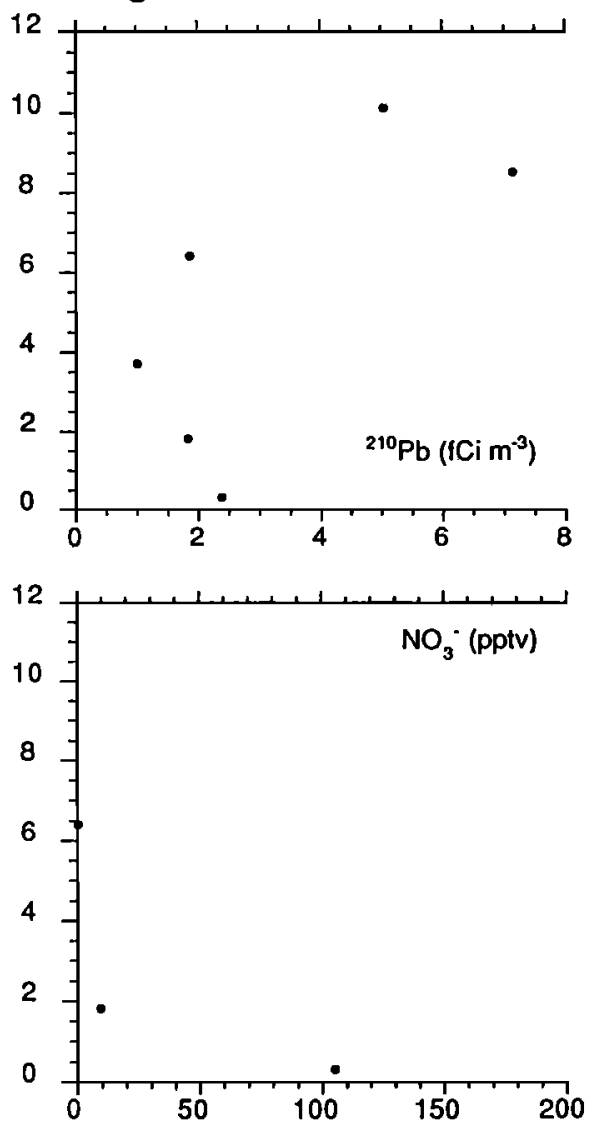
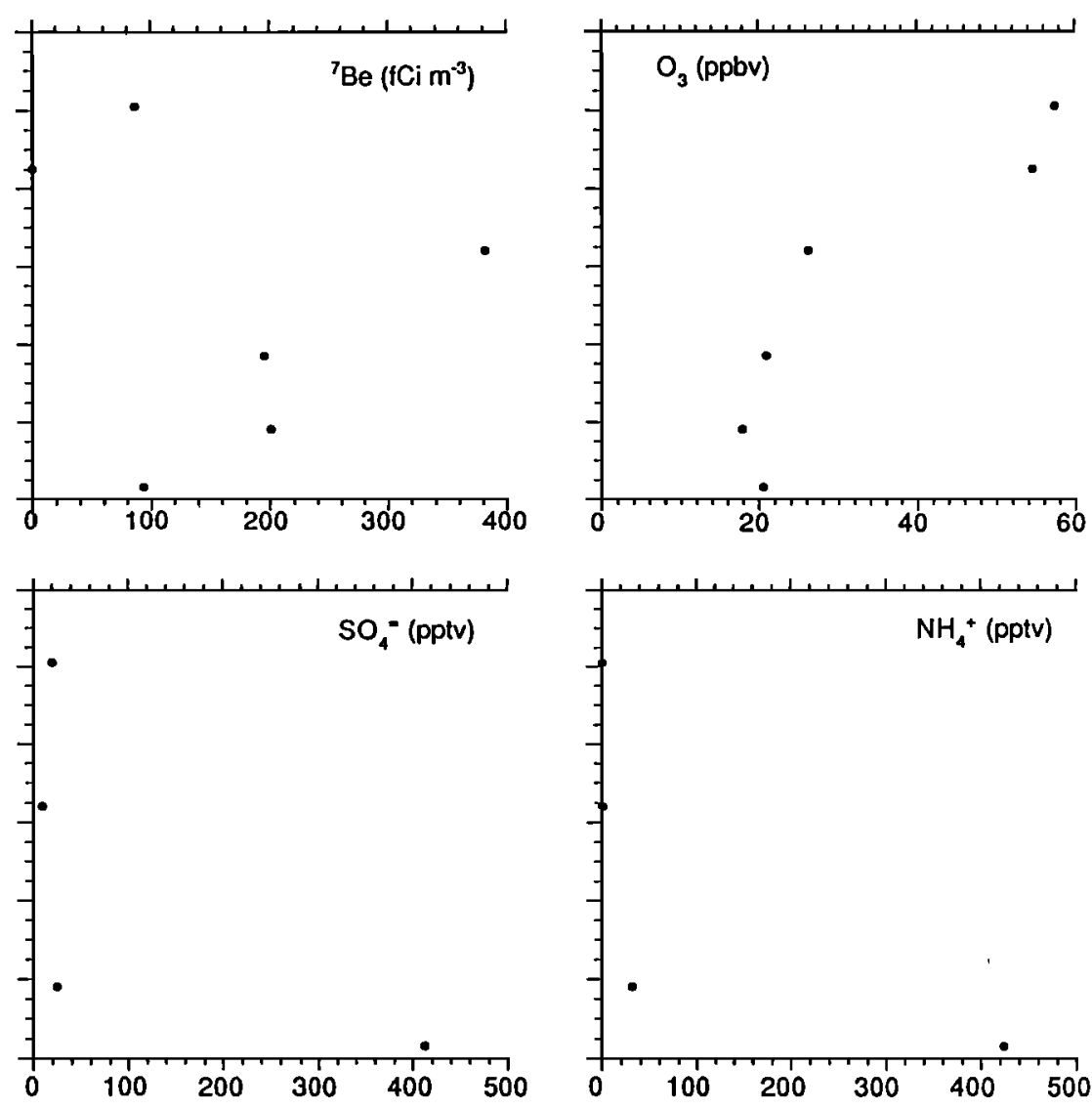

Figure 2. Results for aerosol-associated species and $\mathrm{O}_{3}$ on flight 12, plotted in the same format as Figure 1.

However, stratospheric ozone should be accompanied by ${ }^{7} \mathrm{Be}$ [Dutkiewicz and Husain, 1979, 1985]. Strong correlations were seen between ${ }^{7} \mathrm{Be}$ and $\mathrm{O}_{3}$ on three of the transit flights during PEM-West A (flights 4,5 , and 21 ) but were notably lacking on the flights over the western Pacific (Figure 4)

Enhanced ${ }^{210} \mathrm{~Pb}$ concentrations below $2 \mathrm{~km}$ altitude, both near Asia and over the remote Pacific, were accompanied by elevated $\mathrm{NO}_{3}^{-}, \mathrm{SO}_{4}{ }^{-}$, and $\mathrm{NH}_{4}^{+}$concentrations (Figure 1). We interpret these cases as low-level transport of continental boundary layer air over the ocean with minimal precipitation, a view that is supported by the meteorological analyses [Talbot et al., this issue; Merrill, this issue; Bachmeier et al., this issue]. These cases were identified as "plumes" in the lidar and potential vorticity air mass characterization described by Browell et al. [this issue] and were clearly distinquished from continental outflow that had been processed through convecting clouds ("convective outflowcontinental" in the Browell et al. classification scheme).

A recent three-dimensional modeling experiment also implicates vertical transport of ${ }^{222} \mathrm{Rn}$ in wet convection as a major factor controlling the distribution of ${ }^{210} \mathrm{~Pb}$ in the free troposphere [Balkanski et al., 1993]. The model calculates midtroposphere ${ }^{210} \mathrm{~Pb}$ concentrations over northern hemisphere continents during the summer, and in the tropics most of the year, that are only twofold lower than those in the boundary layer. Uplift of ${ }^{222} \mathrm{Rn}$ in deep wet convection is clearly the cause of these ${ }^{210} \mathrm{~Pb}$ distributions in the model [Balkanski et al., 1993]. The model calculates September-October mean ${ }^{210} \mathrm{~Pb}$ activities for a grid cell in the middle of the near Asia region sampled during PEM-West $A$ of
$12.5,6.5$, and $9 \mathrm{fCi} \mathrm{m}^{-3} \mathrm{STP}$, in the boundary layer, at $6 \mathrm{~km}$ and near $12 \mathrm{~km}$, respectively (D. Jacob, personal communication, 1993). The model results are in accord with our observations up to $6 \mathrm{~km}$ (Figure 1a), but do not reflect the observed decrease in ${ }^{210} \mathrm{~Pb}$ concentration at higher altitudes. The extent of agreement between the model and observations is encouraging, but it is clear that the PEM-West A data set is not extensive enough to constitute a rigorous test of the model.

\section{Deep Wet Convection and Reactive Nitrogen Species}

Balkanski et al. [1993] suggest that the separation of ${ }^{222} \mathrm{Rn}$ (not scavenged) from primary aerosols and soluble gaseous species that react to form secondary aerosols (efficiently scavenged) by the mechanism of deep wet convection makes ${ }^{210} \mathrm{~Pb}$ a poor tracer of continentally derived aerosols. Tsunogai et al. [1988] made the same suggestion on the basis of differing temporal patterns of ${ }^{210} \mathrm{~Pb}$ and $\mathrm{Al}$ concentrations in aerosol samples from six western Pacific stations. Our results seem to support this conclusion, but they also confirm that ${ }^{210} \mathrm{~Pb}$ is a sensitive tracer of continentally influenced air over the Pacific. Balkanski et al. [1993] also speculate that the low solubility of $\mathrm{NO}_{x}$ may allow a significant fraction of boundary layer $\mathrm{NO}_{\mathrm{x}}$ to survive wet convective transport to the middle and upper troposphere, thereby explaining the strong correlation between ${ }^{210} \mathrm{~Pb}$ and nitrate observed at remote islands in the Pacific Ocean [Savoie et al., 1989]. Savoie et al. also invoked convective transport to lift the ${ }^{210} \mathrm{~Pb}$ precursor ${ }^{222} \mathrm{Rn}$ into the free troposphere but suggested that lightning provided the midtropospheric source of $\mathrm{NO}_{\mathrm{x}}$ that was later converted to $\mathrm{NO}_{3}^{-}$. 

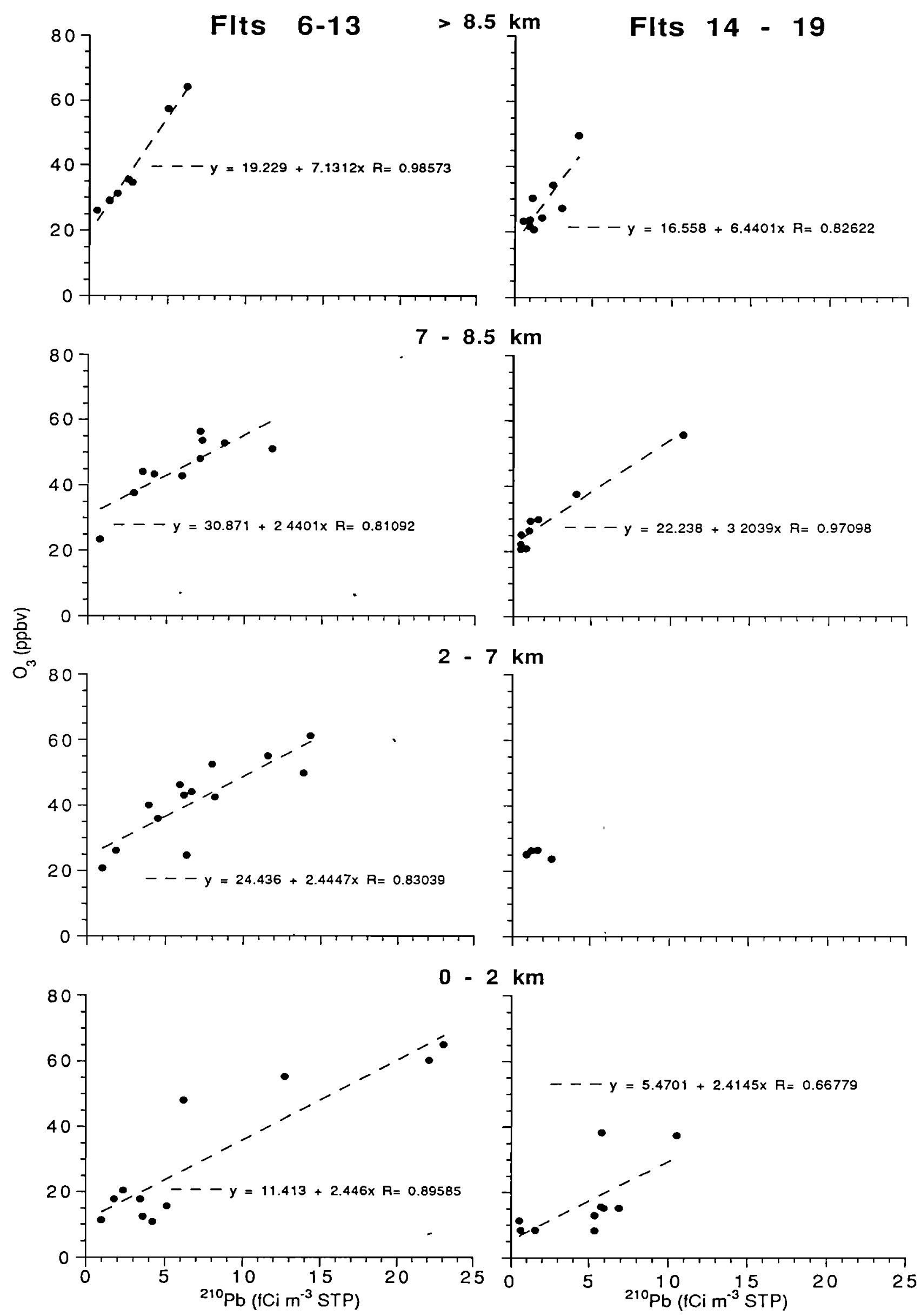

Figure 3. Scatterplots of $\mathrm{O}_{3}$ against ${ }^{210} \mathrm{~Pb}$ for the eight location/altitude bins depicted in Figure 1. 

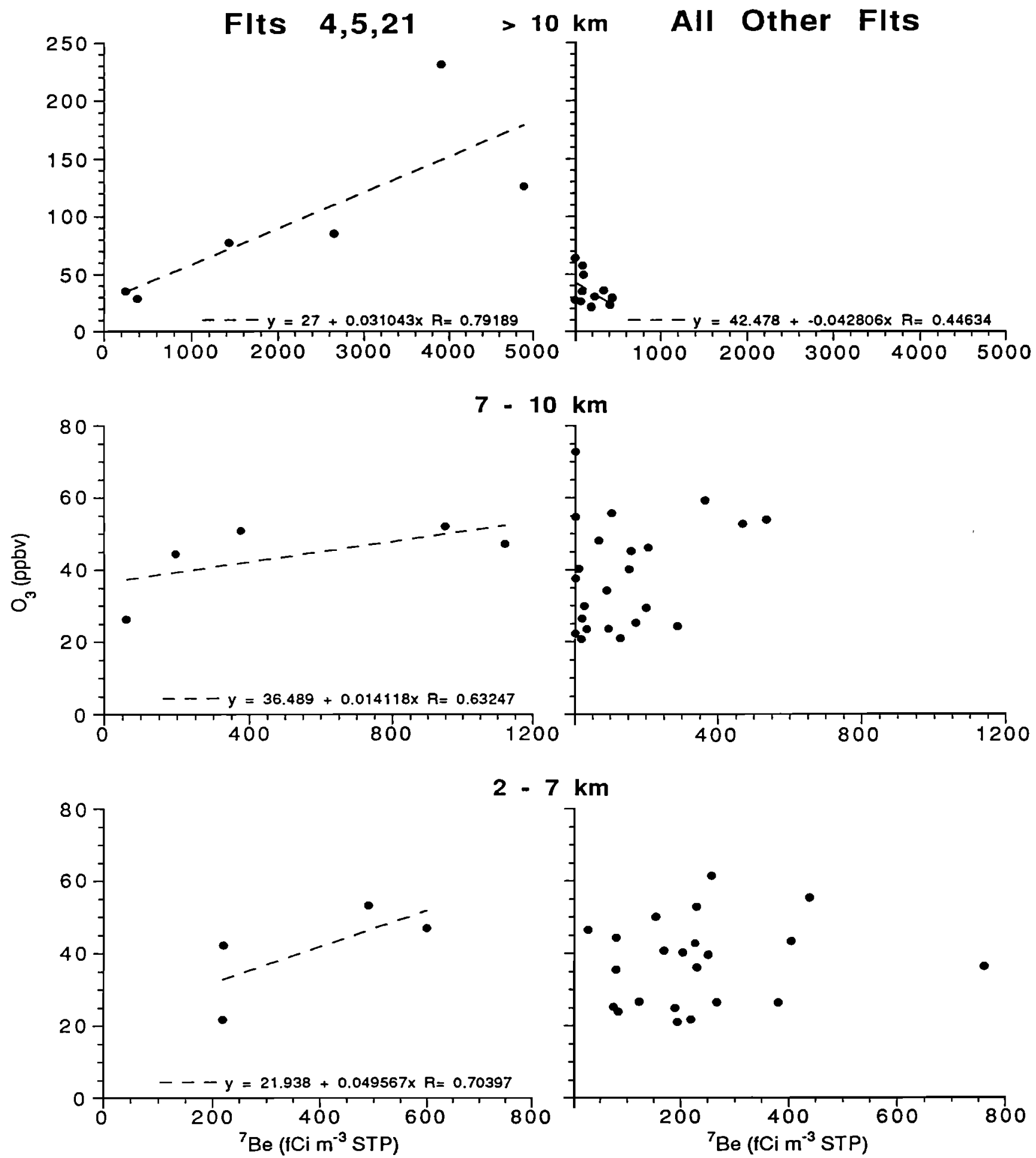

$2 \cdot 7 \mathrm{~km}$

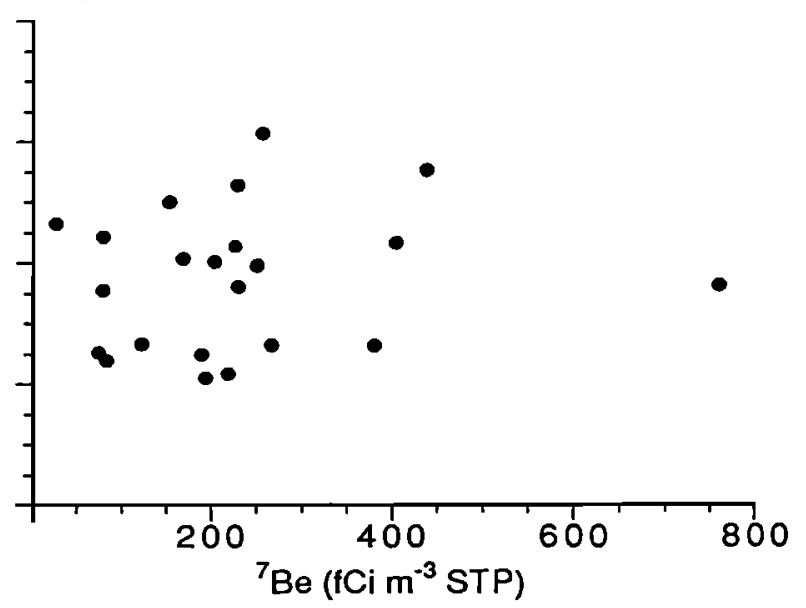

Figure 4. Scatterplots of $\mathrm{O}_{3}$ against ${ }^{7} \mathrm{Be}$ in the free troposphere. The three transit flights $(4,5$, and 21$)$ were flown between California and Alaska, Alaska and Japan, and from Hawaii to California. All remaining flights over the western Pacific are compared to these three. 


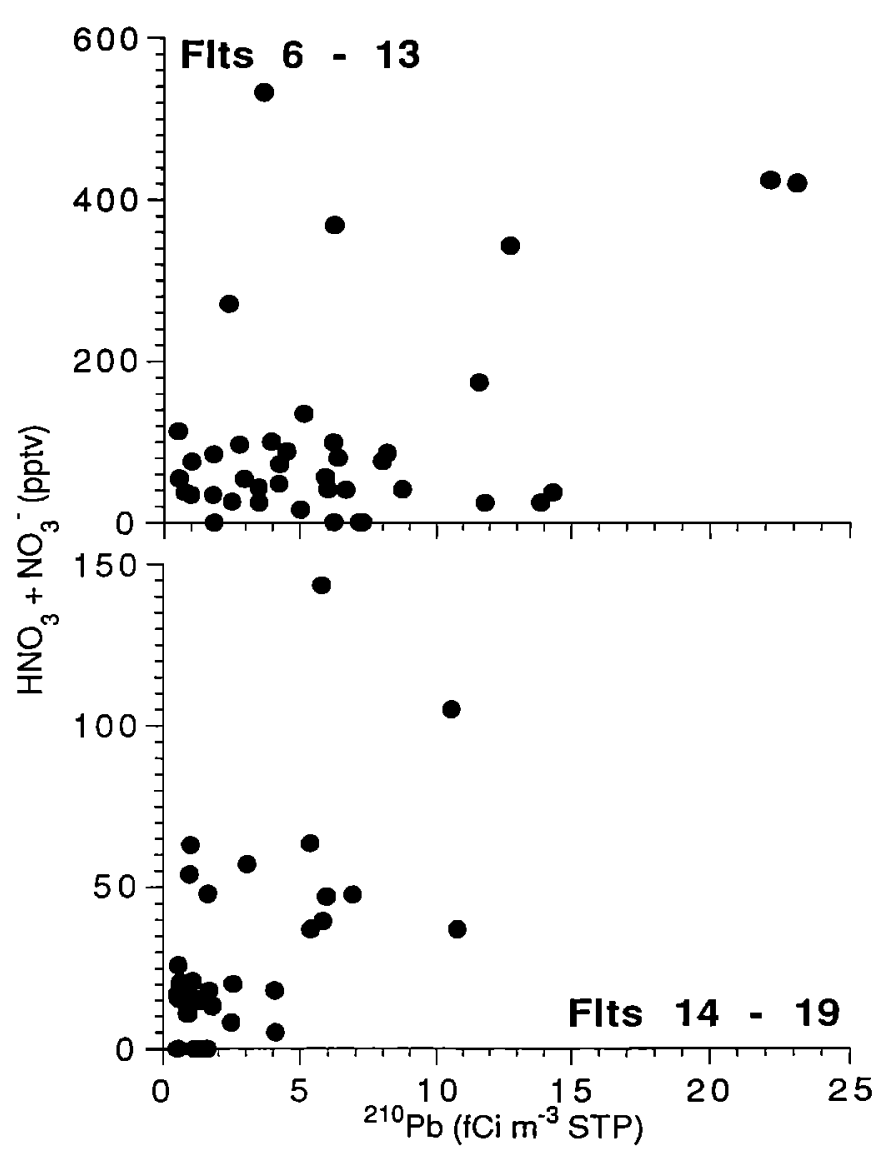

Figure 5. Scatterplots of atmospheric nitrate (aerosol $\mathrm{NO}_{3}^{-}$plus $\mathrm{HNO}_{3}$ ) against ${ }^{210} \mathrm{~Pb}$. Separate plots are shown for the samples collected near Asia and those from the remote western Pacific.

The PEM-West A data set allows a preliminary assessment of these hypotheses.

The filter sampling technique used at the remote island sites is felt to efficiently collect $\mathrm{HNO}_{3}$ in addition to aerosol $\mathrm{NO}_{3}{ }^{-}$[Savoie et al., 1989]. If atmospheric nitrate is considered to be the sum of $\mathrm{NO}_{3}^{-}$and $\mathrm{HNO}_{3}$, the PEM-West $\mathrm{A}$ atmospheric nitrate data show little or no relationship with ${ }^{210} \mathrm{~Pb}$ when results from all altitudes are considered (Figure 5). It may be that the previously noted stratification of the free troposphere during PEM-West $A$ is obscuring any relationships that are present.

The vertical distribution of ${ }^{210} \mathrm{~Pb}$ in the two regions over the western Pacific is compared to those of all measured reactive $N$ species in Figure 6. Near Asia, all of the $\mathrm{N}$ species except PAN are enhanced in the boundary layer relative to the free-tropospheric air just above (Figure 6a), but we do not consider that the ${ }^{210} \mathrm{~Pb}$ enhancement in the boundary layer is related to wet convection (see above). Aerosol $\mathrm{NO}_{3}^{-}, \mathrm{NO}_{\mathrm{x}}$, and $\mathrm{NO}_{\mathrm{y}}$ also increase in the highest-altitude bin near Asia, where ${ }^{210} \mathrm{~Pb}$ concentrations are the lowest of the entire profile. High-altitude aircraft traffic may be an important source of reactive $\mathrm{N}$ in this region [e.g., Kasibhatla, 1993]. Over the remote western Pacific, modest enhancement of ${ }^{210} \mathrm{~Pb}$ concentrations in the boundary layer are accompanied by slightly elevated $\mathrm{NO}_{3}^{-}$concentrations, but concentrations of the other $\mathrm{N}$ species are quite low (Figure 6b). Relatively large enhancements of $\mathrm{NO}_{x}$ and $\mathrm{NO}_{y}$ near $8.5 \mathrm{~km}$ over the remote western Pacific correspond to proportionally smaller increases in ${ }^{210} \mathrm{~Pb}$ and PAN concentrations. Overall, the correspondence between ${ }^{210} \mathrm{~Pb}$ and $\mathrm{NO}_{3}^{-}$or $\mathrm{HNO}_{3}$ appears to be weak.
Scatterplots of atmospheric nitrate versus ${ }^{210} \mathrm{~Pb}$ for each latitude/region bin reinforce the impression that no consistent strong relationships exist in the PEM-West $A$ data set. Atmospheric nitrate and ${ }^{210} \mathrm{~Pb}$ concentrations only covaried in the boundary layer over the remote western Pacific (Figure 7). It is possible that ${ }^{22} \mathrm{Rn}$ decay to ${ }^{210} \mathrm{~Pb}$ occurs more quickly than the conversion of $\mathrm{NO}_{x}$ (from the boundary layer or lightning) to nitrate, but similar plots of $\mathrm{NO}_{\mathrm{x}}$ and $\mathrm{NO}_{\mathrm{y}}$ against ${ }^{210} \mathrm{~Pb}$ (not shown) also indicate little or no correspondence. However, PAN concentrations tended to covary with those of ${ }^{210} \mathrm{~Pb}$ at all altitudes near Asia and in the 7to $8.5-\mathrm{km}$ bin over the remote western Pacific (Figure 8).

The observed correlation between ${ }^{210} \mathrm{~Pb}$ and $\mathrm{PAN}$, alone of the reactive $\mathrm{N}$ species, may be consistent with wet convection of $\mathrm{NO}_{x}$ and ${ }^{222} \mathrm{Rn}$ from the continental boundary layer resulting in strong ${ }^{210} \mathrm{~Pb}-\mathrm{NO}_{3}^{-}$relationships in remote oceanic regions. We hypothesize that the modified boundary layer air that passed through the deep wet convection cycle retained $\mathrm{NO}_{\mathrm{x}}$ and $\mathrm{NMHC}$ in proportions that favored the formation of PAN over inorganic forms of nitrate. As middle to upper tropospheric air over Asia enriched in ${ }^{210} \mathrm{~Pb}$ (and/or ${ }^{222} \mathrm{Rn}$ ) and PAN is advected eastward and subsides somewhere over the Pacific, thermal decomposition of PAN will generate $\mathrm{NO}_{\mathrm{x}}$ far from its initial source [Singh et al., 1987; Singh et al., 1992a, b; this issue]. This $\mathrm{NO}_{\mathrm{x}}$ may then be converted to $\mathrm{NO}_{3}^{-}$and/or $\mathrm{HNO}_{3}$, creating an air mass enriched in both ${ }^{210} \mathrm{~Pb}$ and atmospheric nitrate. If PAN is the initial product of most $\mathrm{NO}_{x}$ lifted to the free troposphere over Asia, the time lag required for its decomposition could account for the ${ }^{210} \mathrm{~Pb}$ rich, but nitrate poor, free-tropospheric air sampled over the western Pacific during PEM-West A. Trajectory analyses indicate that the continental air masses encountered by the DC-8 had generally been over Asia as little as 2 days previously [Talbot et al., this issue]. Older continental air, presumably more prevalent farther from the Asian continent, might be expected to shower tighter relationships between ${ }^{210} \mathrm{~Pb}$ and atmospheric nitrate. Flight 20 , the Mauna Loa flyby conducted during PEM-West A [see Atlas et al., 1995; Hoell et al., this issue] provides some support for this hypothesis.

\section{Older Continental Air Case Study, Flight 20}

The primary objective of the Mauna Loa flyby was intercomparison with ground-based measurements conducted by the MLOPEX team. Sampling from the DC-8 was restricted to altitudes below $5 \mathrm{~km}$. Surface level winds were easterly and back trajectories at low levels indicated transport from near the North American west coast (all meteorological analyses were provided by the GTE project office and are available from the PEM-West A data archive). A midtroposphere ridge of high pressure over Hawaii caused weak subsidence and relatively light winds aloft. Trajectories at the maximum sampling altitudes indicate that air had circled Hawaii with anticyclonic curvature for the previous 5 - 7 days. None of these trajectories ventured more than $10^{\circ}$ away from Hawaii, so it is unclear whether any continentally influenced air in the free troposphere originated over Asia or North America.

Lead 210 concentrations above the boundary layer ranged 3 $8 \mathrm{fCi} \mathrm{m}^{-3}$ STP and decreased toward the surface (Figure 9), indicating long-range transport of continental air in the free troposphere. In this case the altitude profiles of all reactive $\mathrm{N}$ species were quite similar to that of ${ }^{210} \mathrm{~Pb}$. It should be noted that PAN mixing ratios were nearly fivefold lower than those observed in younger continental outflow near Asia (compare Figures 6a and 9). The much higher ${ }^{7} \mathrm{Be}$ concentrations at $5 \mathrm{~km}$ over Hawaii relative to the majority of PEM-West A flights (compare Figures 1 and 9) appear to reflect the input of upper tropospheric/lower stratospheric air during high-level transport, with little subsequent 

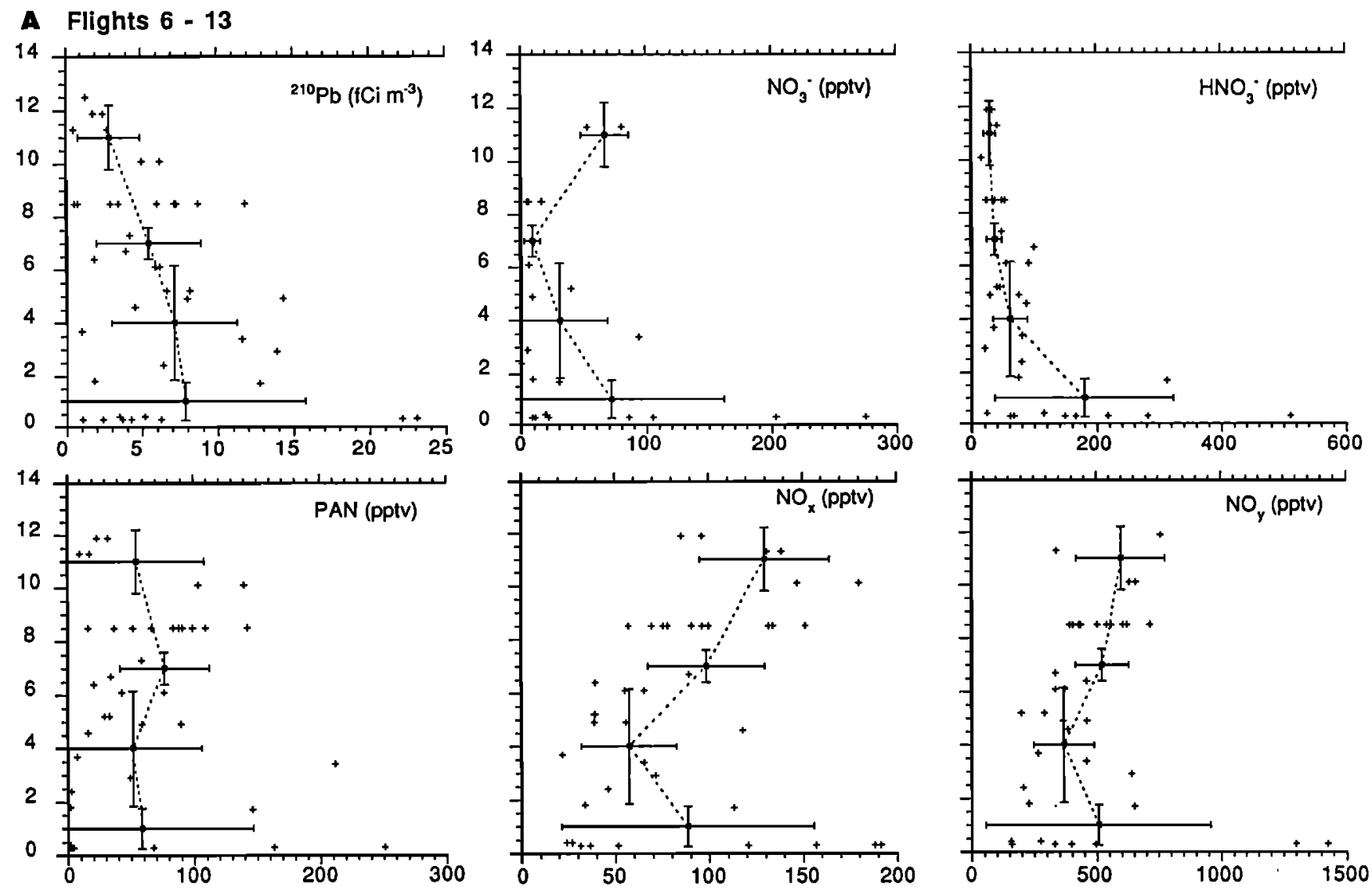

Flights $14-19$
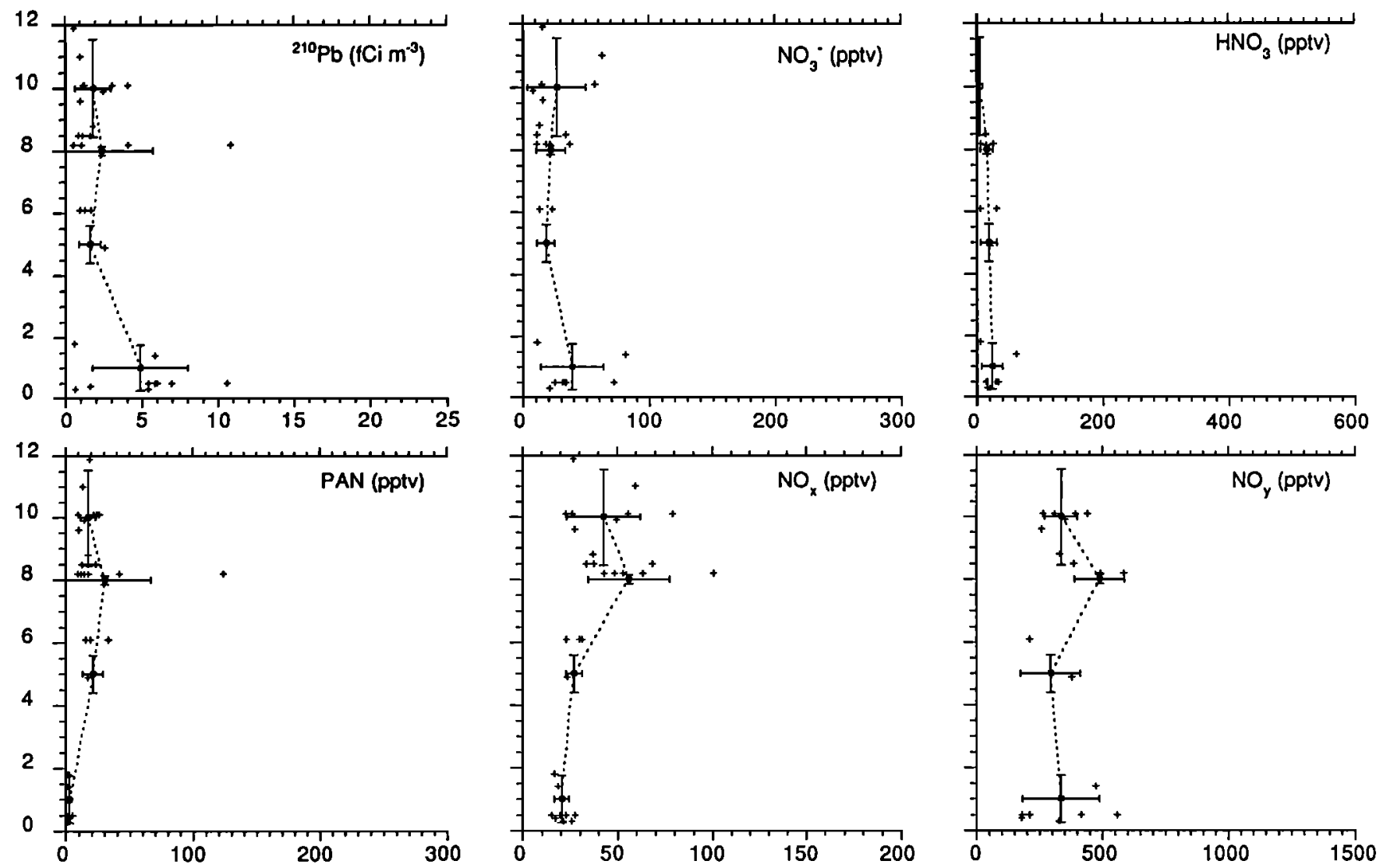

Figure 6. Comparison of the altitude distributions of ${ }^{210} \mathrm{~Pb}$ and the major reactive nitrogen species measured during PEM-West A. Sampling frequencies for the nitrogen species are much higher than the aerosol sampling; data shown here have been averaged to correspond to the intervals represented by each aerosol sample. Geographic separation into near Asia (a) and remote western Pacific (b) subsets has been maintained. 


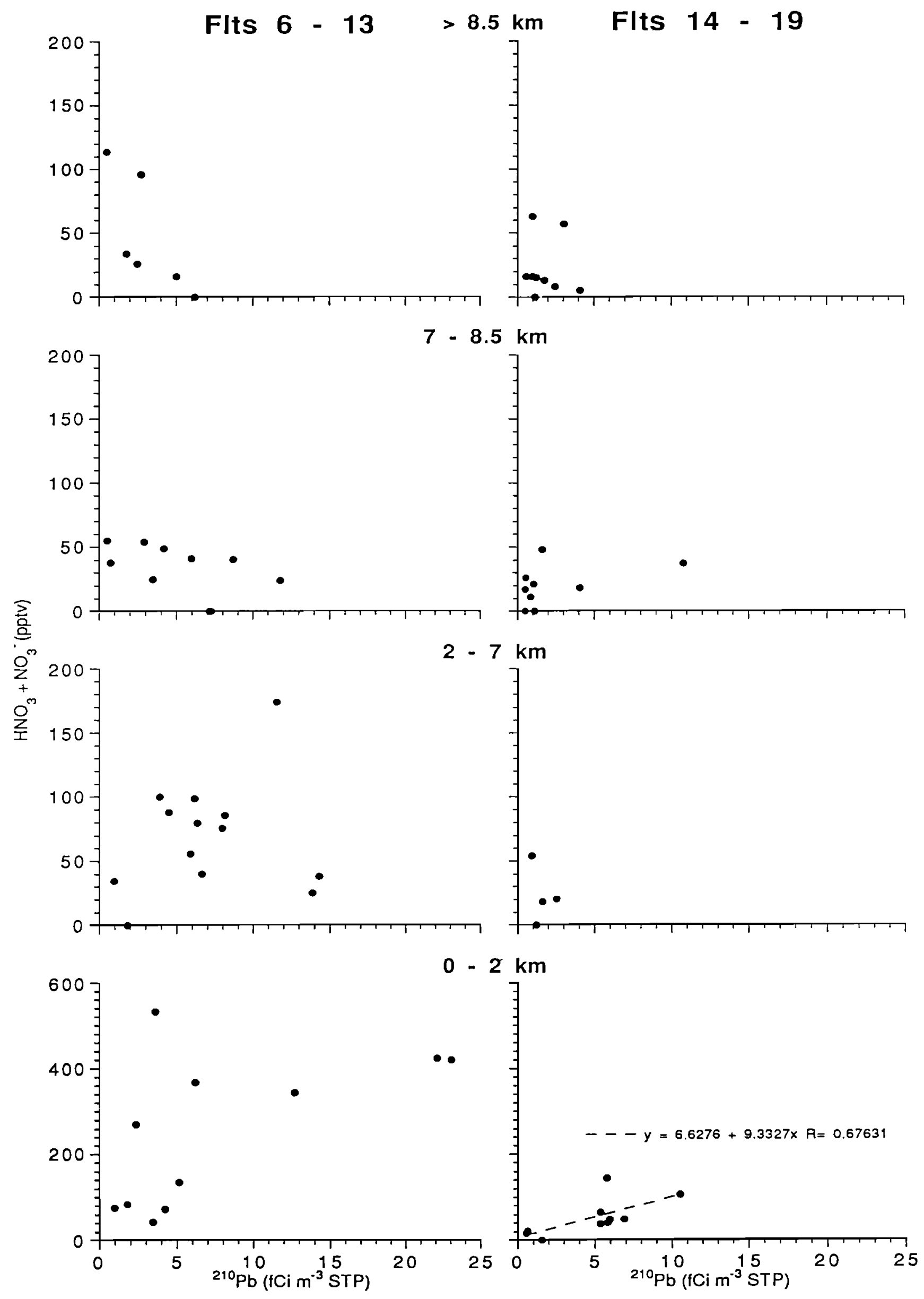

Figure 7. Scatterplots of atmospheric nitrate $\left(\mathrm{NO}_{3}^{-}\right.$plus $\left.\mathrm{HNO}_{3}\right)$ against ${ }^{210} \mathrm{~Pb}$ for the eight location/altitude bins depicted in Figure 6. 


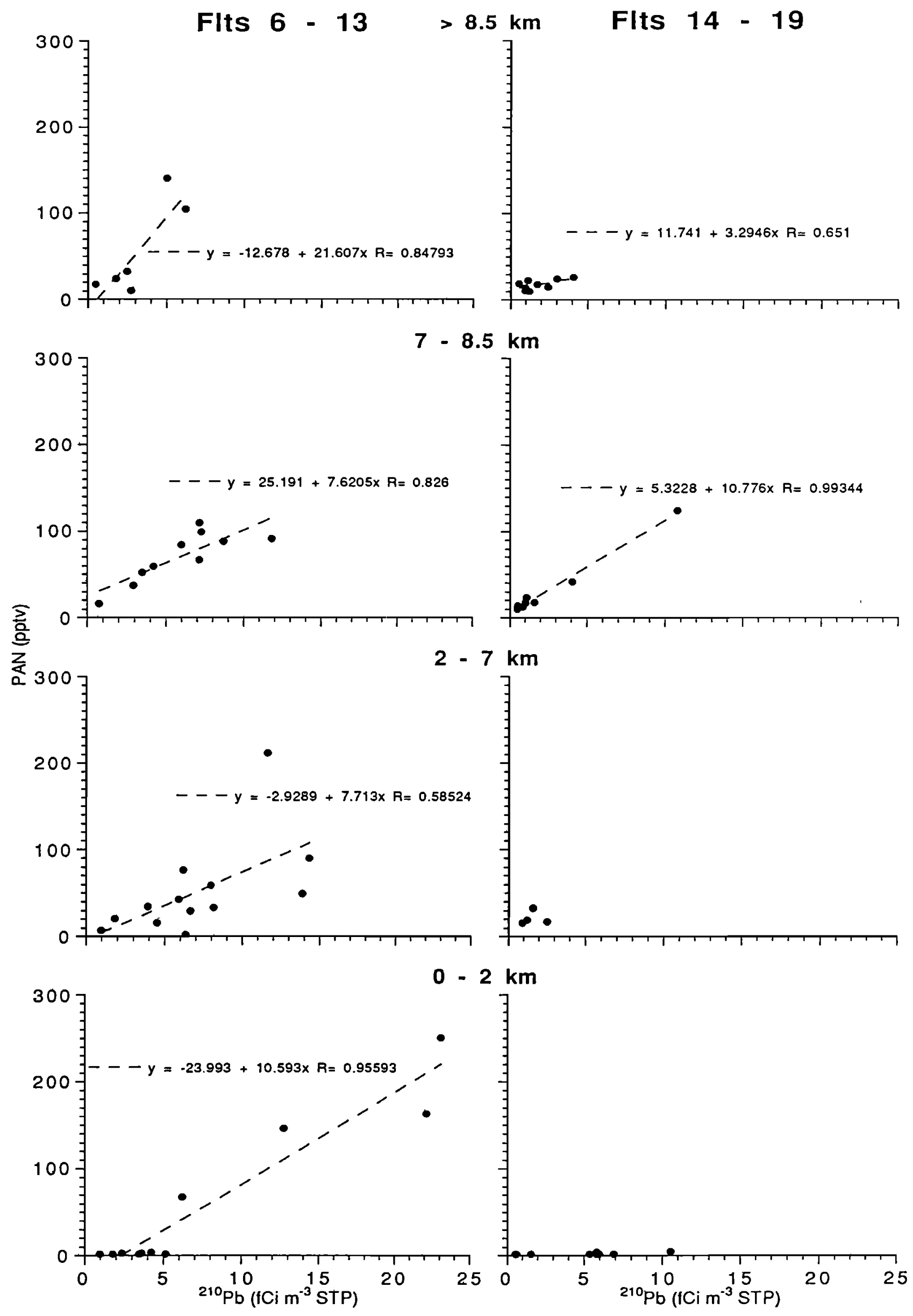

Figure 8. As in Figure 7 but for peroxyacetylnitrate against ${ }^{210} \mathrm{~Pb}$. 
Flight 20
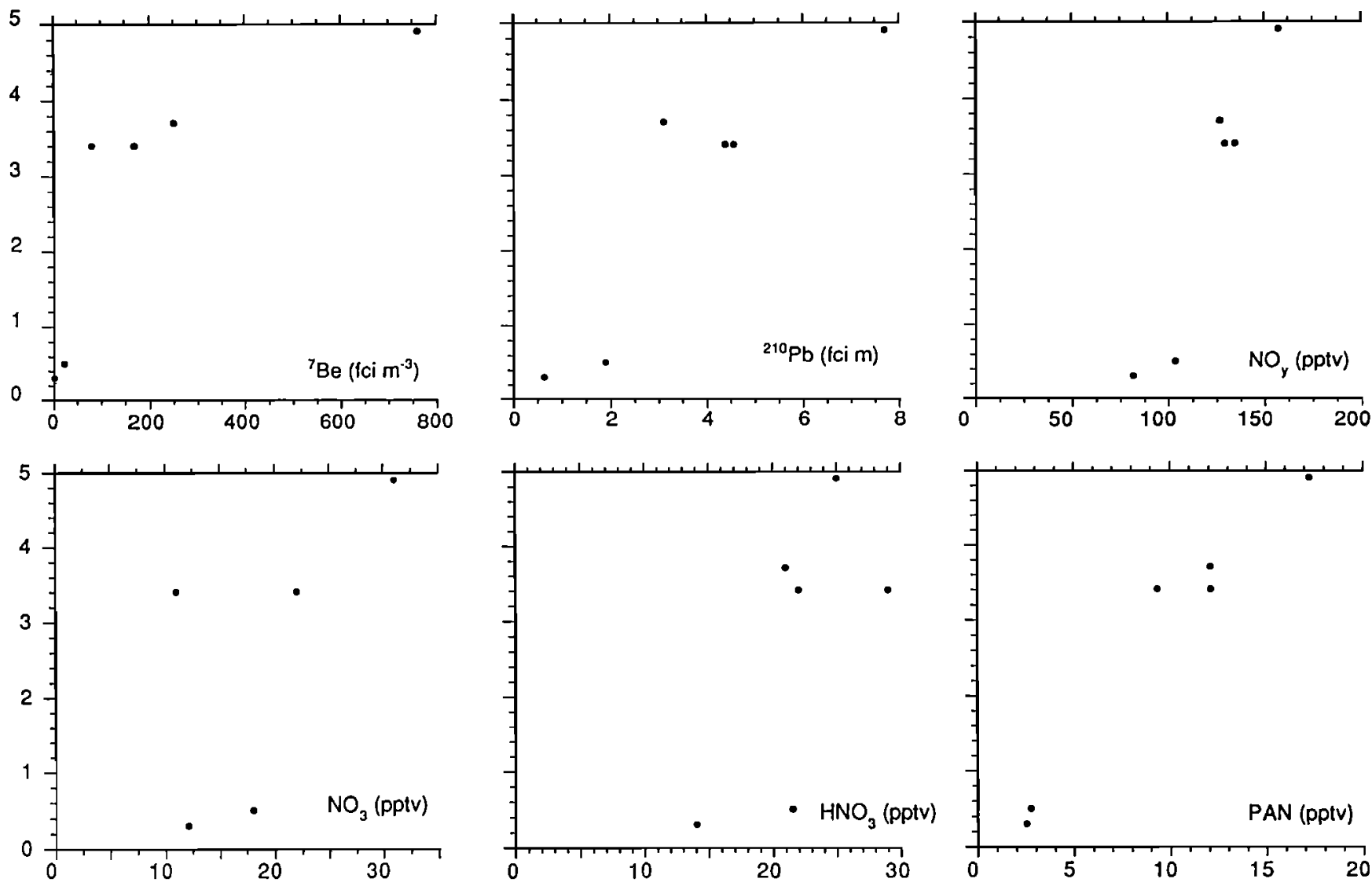

Figure 9. Altitude distributions of ${ }^{7} \mathrm{Be},{ }^{210} \mathrm{~Pb}, \mathrm{NO}_{3} ;, \mathrm{HNO}_{3}, \mathrm{PAN}$, and $\mathrm{NO}_{\mathrm{y}}$ on flight 20 , the Mauna Loa flyby.

scavenging. None of the soluble aerosol-associated species except $\mathrm{NO}_{3}^{-}$increased with altitude, suggesting they were scavenged at some point in the history of this air mass when ${ }^{210} \mathrm{~Pb}$ and nitrate were still present in the form of insoluble precursors. As we have seen, wet convection over continents appears the most likely mechanism that could enrich ${ }^{210} \mathrm{~Pb}$ relative to other aerosolassociated species in free tropospheric air over the ocean. In this particular air mass, greater than one week removed from last direct continental influence, atmospheric nitrate variations with altitude correspond to those of ${ }^{210} \mathrm{~Pb}$.

\section{Summary and Conclusions}

The atmosphere over the Pacific Ocean just east of the Asian continent and in a broader region centered on Guam was sampled from the NASA AMES DC-8 in September - October 1991. Only a few weeks were spent in any given region, so the findings must be regarded as a series of snapshots of atmospheric composition that resulted from the specific meteorological conditions prevailing during the period of the PEM-West A mission. This paper has focused primarily on the composition of aerosols. Despite the short-term nature of the investigation the findings appear to be consistent over large geographic regions and with a conceptual model relating deep wet convection over Asia to the composition of the free troposphere downwind over the western Pacific ocean.

Concentrations of ${ }^{7} \mathrm{Be}$ and soluble ionic species were quite low in most aerosol samples collected in the free troposphere, both near Asia and farther east near Guam. In contrast, ${ }^{210} \mathrm{~Pb}$ concentrations were higher than expected between 2 and $14 \mathrm{~km}$ near
Asia and in a narrower altitude range near $8 \mathrm{~km}$ over the more remote western Pacific. Ozone concentration variations in the free troposphere tended to follow those of ${ }^{210} \mathrm{~Pb}$. Concentrations of ${ }^{210} \mathrm{~Pb}$ and nearly all of the soluble aerosol-associated ionic species in the boundary layer increased markedly when continental air was advected over the ocean at low altitudes.

Deep wet convection over Asia appears to provide a mechanism to rapidly lift continental boundary layer air to the middle and upper troposphere, where strong zonal winds can subsequently advect it over the Pacific. Intense precipitation in these systems apparently scavenges aerosols and soluble gases from the ascending air without depleting ${ }^{222} \mathrm{Rn}$ and sparingly soluble $\mathrm{O}_{3}$ precursors. As a result, ${ }^{210} \mathrm{~Pb}$ and $\mathrm{O}_{3}$ tended to be correlated in the free troposphere 2- 5 days downwind of Asia. It has recently been suggested that the solubility of $\mathrm{NO}_{\mathrm{x}}$ is low enough that deep wet convection could also lift $\mathrm{NO}_{x}$ rapidly into the free troposphere, which might account for the strong correlations between ${ }^{210} \mathrm{~Pb}$ and $\mathrm{NO}_{3}{ }^{-}$reported from remote ocean islands. During PEM-West $\mathrm{A}$, no relationships were found between ${ }^{210} \mathrm{~Pb}$ and inorganic nitrate in the free troposphere, rather concentrations of PAN correlated strongly with those of ${ }^{210} \mathrm{~Pb}$. We hypothesize that the composition of modified continental boundary layer air after wet convective processing favors production of PAN over inorganic $\mathrm{NO}_{3}{ }^{-}$, at least within the short periods of aging represented by the PEM-West $A$ samples. It is likely that subsidence of this ${ }^{210} \mathrm{~Pb}$ - and PAN-rich air farther to the east results in thermal decomposition of PAN to $\mathrm{NO}_{\mathrm{x}}$ and subsequent production of $\mathrm{NO}_{3}^{-}$and $\mathrm{HNO}_{3}$, thereby accounting for the correlation between ${ }^{210} \mathrm{~Pb}$ and nitrate. 
It should be borne in mind that PEM-West $A$ was scheduled during the fall in order to characterize atmospheric composition over the Pacific at a time when continental influence should be at its minimum. The results presented herein revealed significant continental influence even during this season, but the impact was largely restricted to those tracers of continental air that are relatively unaffected by precipitation scavenging processes. Even larger Asian influence on the composition of the atmosphere over the western Pacific should be expected during the spring and summer "dust" season.

\section{References}

Atlas, et al., MLOPEX intercomparison, J. Geophys. Res., in press, 1995. Bachmeier, A. S., R. E. Newell, M. C. Shipham, Y. Zhu, D. R. Blake, and E. V. Browell, PEM-West A: Meteorological overview, J. Geophys. Res., this issue.

Balkanski, Y. J., D. J. Jacob, R. Arimoto and M. A. Kritz, Long-range transport of radon-222 over the North Pacific Ocean: Implications for continental influence, J. Atmos. Chem., 14, 353-374, 1992.

Balkanski, Y. J., D. J. Jacob, G. M. Gardner, W. C. Graustein, and K. K Turekian, Transport and residence times of tropospheric aerosols inferred from a global three-dimensional simulation of ${ }^{210} \mathrm{~Pb}, J$. Geophys. Res., 20, 573-20, 586, 1993.

Bhandari, N., D. Lal, and Rama, Stratospheric circulation studies based on natural and artificial radioactive tracer elements, Tellus, 18, 391-405, 1966.

Browell et al., Large-scale air mass characteristics observed over the western Pacific during the summertime, J. Geophys. Res, this issue

Cain, S. A., M. Ram, and D. B. Taulbee, Design of a shrouded probe for airborne aerosol sampling (abstract), Eos Trans. $A G U, 74(16), 71$, 1993.

Danielsen, E. F., In situ evidence of rapid, vertical, irreversible transport of lower tropospheric air into the lower tropical stratosphere by convective cloud turrets and by larger-scale upwelling in tropical cyclones, J. Geophys. Res., 98, 8665-8681, 1993.

Dibb, J. E., Beryllium 7 and lead 210 in the atmosphere and surface snow over the Greenland ice sheet in the summer of 1989, J. Geophys. Res., 95, 22,407-22,415, 1990a.

Dibb, J. E., Recent deposition of ${ }^{210} \mathrm{~Pb}$ on the Greenland ice sheet: Variations in space and time, Ann. Glaciol., 14, 51-54, 1990b.

Dibb, J. E., R. W. Talbot, and G. L. Gregory, Beryllium 7 and lead 210 in the western hemisphere Arctic atmosphere: Observations from three recent aircraft-based sampling programs, J. Geophys. Res., 97, 16,709$16,715,1992$.

Dutkiewicz, V. A., and L. Husain, Determination of stratospheric ozone at ground level using ${ }^{7} \mathrm{Be} / \mathrm{ozone}$ ratios, Geophys. Res. Lett., 6, 171-174, 1979.

Dutkiewicz, V. A., and L. Husain, Stratospheric and tropospheric components of ${ }^{7} \mathrm{Be}$ in surface air, J. Geophys. Res., 90, 5783-5788, 1985.

Flynn, W. W., The determination of low levels of polonium-210 in environmental materials, Anal. Chim. Acta., 43, 221-227, 1968

Gao, Y., R. Arimito, M. Y. Zhou, J. T. Merrill, and R. A. Duce, Relationships between the dust concentrations over eastern Asia and the remote North Pacific, J. Geophys. Res., 97, 9867-9872, 1992.

Gregory, G. L., A. S. Bachmeier, D. R. Blake, B. G. Heikes, D. C Thornton, A. R. Bandy, J. E. Bradshaw, and Y. Kondo, Chemical signatures of aged Pacific marine air: Mixed layer and free troposphere as measured during PEM-West A, J. Geophys. Res., this issue.

Hoell, J. M., et al., Pacific Exploratory Mission-West: September-October 1991, J. Geophys. Res., this issue.

Huebert, B. J., G. Lee, and W. L. Warren, Airbome aerosol inlet passing efficiency measurement, $J$. Geophys. Res., 95, 16,369-16,381, 1990.

Kasibhatla, P. S., NO from sub-sonic aircraft emissions: A global threedimensional model study, Geophys. Res. Lett, 20, 1707-1710, 1993.

Kleinman, L. I., and P. H. Daum, Vertical distribution of aerosol particles, water vapor, and insoluble trace gases in convectively mixed air, $J$. Geophys. Res., 96, 991-1005, 1991.

Kritz, M. A., J. C. Le Roulley, and E. F. Danielsen, The China Clipperfast advective transport of radon-rich air from the Asian boundary layer to the upper troposphere near California, Tellus, 42B, 46-61, 1990.

Kritz, M. A., S. W. Rosner, K. K. Kelly, M. Loewenstein, and K. R. Chan, Radon measurements in the lower tropical stratosphere: Evidence for rapid vertical transport and dehydration of tropospheric air, J. Geophys. Res., 98, 8725-8736, 1993.

Lambert, G., G. Polian, J. Sanak, B. Ardouin, A. Buisson, A. Jegou, and
J. C. Le Roulley, Cycle du radon et de ses descenants: Application a l'étude des echanges troposphère-stratosphère, Ann. Geophys., 38, 497$531,1982$.

McFarland, A. R., C. A. Otiz, M. E. Moore, R. E. DeOtte Jr., and S. Somasundaram, A shrouded aerosol sampling probe, Environ. Sci. Technol., 23, 1487-1492, 1989.

Merrill, J. T., Trajectory results and interpretation for PEM-West A, $J$. Geophys. Res., this issue.

Merrill, J. T., M. Uematsu, and R. Bleck, Meteorological analysis of longrange transport of mineral aerosols over the North Pacific, J. Geophys. Res., 94, 8584-8598, 1989.

Moore, H. E., S. E. Poet, and E. A. Martell, ${ }^{222} \mathrm{Rn},{ }^{210} \mathrm{~Pb},{ }^{210} \mathrm{Bi}$, and ${ }^{210} \mathrm{Po}$ profiles and aerosol residence times versus altitude, J. Geophys. Res., 78, 7065-7075, 1973.

Newell, R. E., S. T. Shipley, V. S. Connors, and H. G. Reichle Jr., Regional studies of potential carbon monoxide sources based on space shuttle and aircraft measurements, J. Atmos. Chem., 6, 61-81, 1988.

Paluch, I. R., D. H. Lenschow, J. G. Hudson, and R. Pearson Jr., Transport and mixing processes in the lower troposphere over the ocean, J. Geophys. Res., 97, 7527-7541, 1992.

Pickering, K.E., A.M. Thompson, J.R. Scala, W.-K. Tao, R.R. Dickerson, and J. Simpson, Free tropospheric ozone production following entrainment of urban plumes into deep convection, $J$. Geophys. Res., 97, 17, 985-18,000, 1992.

Porter, J. N., A. D. Clarke, G. Ferry, and R. F. Pueschel, Aircraft studies of size-dependent aerosol sampling through inlets, J. Geophys. Res., 97, 3815-3824, 1992.

Prospero, J. M., D. Savoie, R. T. Nees, R. A. Duce, and J. T. Merrill, Particulate sulfate and nitrate in the boundary layer over the North Pacific Ocean, J. Geophys. Res., 90, 10,586-10,596, 1985.

Savoie, D. L., J. M. Prospero, J. T. Merrill, and M. Uematsu, Nitrate in the atmospheric boundary layer of the tropical South Pacific: Implications regarding sources and transport, J. Atmos. Chem., 8, 391415, 1989.

Singh, H. B., Reactive nitrogen in the troposphere, Environ. Sci. Technol., $21,320-327,1987$.

Singh, H. B., D. O'Hara, D. Herlth, J. D. Bradshaw, S. T. Sandholm, G. L. Gregory, G. W. Sachse, D. R. Blake, P. J. Crutzen, and M. A. Kanakidou, Atmospheric measurements of peroxyacetyl nitrate and other organic nitrates at high latitudes: Possible sources and sinks, $J$. Geophys. Res., 97, 16,511-16522, 1992.

Singh, H. B., D. Herith, D. O'Hara, K. Zahnle, J. D. Bradshaw, S. T. Sandholm, R. Talbot, P. J. Crutzen, and M. Kanakidou, Relationship of peroxyacetyl nitrate to active and total odd nitrogen at northern high latitudes: Influence of reservoir species on $\mathrm{NO}_{x}$ and $\mathrm{O}_{3}, J$. Geophys. Res., 97, 16,523-16,530, 1992.

Singh, H. B., et al., Reactive nitrogen and ozone over the western Pacific: Distribution, partitioning and sources, $J$. Geophys. Res., this issue.

Smyth, et. al., Comparison of Free Tropospheric Western Pacific Air Mass Classification Schemes for the PEM-WEST A Experiment, J. Geophys. Res., this issue.

Talbot, R. W., R. C. Harriss, F. V. Browell, G. L. Gregory, D. I. Sebacher, and S.M. Beck, Distribution and geochemistry in the tropical North Atlantic troposphere: Relationship to Saharan dust, J. Geophys. Res., 91, 5173-5182, 1986.

Talbot, R. W., A. S. Vijgen, and R. C. Harriss, Soluble species in the Arctic summer troposphere: Acidic gases, aerosols, and precipitation, J. Geophys. Res., 97, 16,531-16,543, 1992.

Talbot, R. W., et al., Chemical characteristics of continental outflow from Asia to the troposphere over the western Pacific Ocean during September-October 1991: Results from PEM-WEST A, J. Geophys. Res. this issue.

Tsunogai, S, T. Kurata, T. Suzuki, and K. Yokota, Seasonal variation of atmospheric ${ }^{210} \mathrm{~Pb}$ and $\mathrm{Al}$ in the western North Pacific region, J. Atmos. Chem., 7, 389-407, 1988.

J. D. Bradshaw and S. T. Sandholm, Georgia Institute of Technology, Atlanta, GA 30332.

J. E. Dibb, R. W. Talbot, and K. I. Klemm, Institute for the Study of Earth, Oceans, and Space, University of New Hampshire, Morse Hall, 39 College Road, Durham, NH 03824-3525.

G. L. Gregory, Atmospheric Sciences Division, NASA Langley Research Center, Hampton, VA 23665.

H. B. Singh, NASA Ames Research Center, Moffet Field, CA 94035.

(Received Janurary 10, 1994; revised November 17, 1994; accepted November 25, 1994.) 